2020 (114): 7-39.

(C) A szerzö(k) 2020

replika.hu/replika/114

\title{
Bognár Bulcsu
}

\section{Az ökológıaı kommunıkácıó lehetôségeı és horlátaı a modernitásban}

Társadalomelméletı észrevételek a környezetvédelem témájához

\begin{abstract}
Absztrakt: A tanulmány az ökológiai kommunikáció társadalomelméleti vonatkozásait boncolja funkcionalista nézőpontból. Az elemzés a modern társadalom részrendszereinek a reakcióját értelmezi. Azt vizsgálja, hogy a társadalom fő szegmensei (gazdaság, politika, oktatás stb.) miképpen válaszolnak a környezeti kihívásokra, illetve az ezt megjelenítő mozgalmak kommunikációjára. Az elemzés ekképpen az ökológiai kommunikáció hatását és lehetőségeit vizsgálja. Az írás arra fókuszál, milyen okai lehetnek annak, hogy a társadalom nagy részterületei viszonylagos érdektelenséget mutatnak a környezetvédelemmel kapcsolatban, vagy csak nehezen és lassan reagálnak a környezeti kihívásokra. Másrészt a tanulmány azt elemzi, hogy a környezeti szempontok hogyan tudnak nagyobb szerepet betölteni a társadalmi kommunikációban. Az elemzés kitér arra, hogy az eddigi ökológiai kommunikáció milyen részeredményeket ért el, illetve melyek azok a strukturális változások a társadalomban, amelyek a környezetvédelemnek nagyobb mozgásteret kínálnak. Az írás utolsó egysége az ökológiai kommunikáció és a társadalmi miliők kapcsolatának hazai vonatkozásait értelmezi az értékkutatások bevonásával.
\end{abstract}

Kulcsszavak: társadalomelmélet, rendszerelmélet, ökológiai kommunikáció, értékkutatások, társadalmi miliők 
2019-ben a klímasztrájkot választotta az év szavának a Collins szótár, amely szerint a kifejezést százszor többször használták ebben az évben, mint a megelőző időszakban. Ez is az egyik jele a környezeti kérdések erőteljesen növekvő jelenlétének a közbeszédben, ami abból is jól látszik, hogy a környezeti veszélyekkel kapcsolatos híradások mostanában napi rendszerességgel jelennek meg a tömegmédia csatornáin. A társadalomra és a Földre leselkedő veszélyeket taglaló tudósítások, elemzések egyre inkább a híroldalak, napilapok címlapjára kerülnek. Érzékelhetően megnőtt tehát a környezeti kérdésekkel kapcsolatos hírek súlya, és egyre fontosabb szerepet játszanak a közéleti megnyilatkozásokban és a nyilvánosság fórumain is.

Az ökológiai kérdések taglalása természetesen nem új jelenség, de most fordul elő először, hogy globálisan hangsúlyos kérdésként jelenik meg, és egyre inkább állásfoglalásra sarkallja a közélet iránt nem feltétlenül érdeklődőket is. Van azonban egy ezzel ellentétes tapasztalatunk is, nevezetesen, hogy a bolygónkat és a társadalmat veszélyeztető környezeti hatások ecsetelése (vagy akár a közeli jövőben bekövetkező klímakatasztrófák prognosztizálása) nem gyakorol jelentős hatást a társadalom müködésére. A későbbiekben taglalt regionális különbségeken túl az látható, hogy a politika, a gazdaság, a jogrendszer és más társadalmi területek müködése többnyire a megszokott kerékvágásban zajlik, a döntésekben a környezetvédelem, az ökopolitika kérdései zömében csak partikulárisan jelennek meg, vagy egyes nagy történeti régiókban a környezeti mozgalmak által jelzett veszélyek teljes negligálásával hozzák a döntéseket. A társadalmat alapvetően veszélyeztető ökológiai válságot megfogalmazó mozgalmak egyfelől az utolsó utáni pillanatról beszélnek és azonnali radikális beavatkozást követelnek, míg a társadalom nagy területei számára a környezetvédelem kérdése leginkább a megszokott müködést zavaró tényezőként jelenik meg. A továbbiakban ennek a kettősségnek a jobb megértésére fókuszálok. ${ }^{1}$

E tanulmány a kiterjedt kérdéskör társadalomelméleti vonatkozásait boncolgatja. Abból indul ki, hogy az ökológiai probléma nem korlátozódik a társadalom gazdasági és politikai szférájára, vagyis a jelenség megértéséhez a társadalom egészét kell górcső alá venni. Azt igyekszem megvizsgálni, hogy a modern társadalom meglehetősen bonyolult müködése alapján miképpen reagál a környezeti kihívásokra, illetve az ezt megjelenítő mozgalmak kommunikációjára. Az elemzés ekképpen az ökológiai kommunikáció hatását és lehetőségeit vizsgálja. Arra vagyok kíváncsi, hogy a környezeti veszélyek hangsúlyos tematizálása, a különböző protesztmozgalmakban megmutatkozó társadalomkritikai olvasatok mennyiben képesek felhívni a figyelmet a környezetszennyezés veszélyeire, és mennyire képesek új irányt adni a társadalom müködésének.

A tanulmány ezentúl azt is vizsgálja, hogy mivel magyarázható az ökológiai mozgalmak viszonylagos sikertelensége az elmúlt évtizedekben: mi az oka annak, hogy hosszú ideig sehol sem sikerült áttörést elérni a környezetvédelem területén és miért nem váltak még most sem gyakorlattá a mozgalmak radikális követelései. Azt a kérdést járom körbe, milyen okai lehetnek annak, hogy a társadalom nagy részterületei viszonylagos érdektelenséget mutatnak a környezetvédelemmel kapcsolatban, vagy csak nehezen és lassan reagálnak a környezeti kihívásokra. Az elemzés végén pedig annak bemutatására törekszem, hogy a környezeti szempontok hogyan tudnak nagyobb szerepet betölteni a társadalmi kommunikációban:

1 Erre a kettősségre utalt Lányi András is, amikor a zöldmozgalom követeléseivel szembeni érzéketlenséget tapasztalta (Lányi 2000). 
az eddigi ökológiai kommunikáció milyen részeredményeket ért el, illetve melyek azok a strukturális változások a társadalomban, amelyek a környezetvédelemnek nagyobb mozgásteret kínálnak, és ezáltal az nagyobb eséllyel válhat képessé az ökológiai szempontok társadalmi érvényesítésére. A tanulmány funkcionalista nézőpontból szemléli a jelenségeket, és elsősorban Niklas Luhmann szociológiaelmélete mentén indul el, hogy majd a kultúr- és értékszociológiai vizsgálatok bevonásával védhető(bb) válaszokhoz kerüljön közelebb.

\section{A társadalmi mozgalmak és a környezetvédelem}

A környezetvédelem több évtizedes története összeforrott a társadalmi mozgalmak történetével. Ebben feltehetően az játszott szerepet, hogy a környezetvédelem - témájából adódóan radikálisan másképp viszonyult a közéleti kérdésekhez. Az újszerü megközelítés leginkább abban érhető tetten, hogy perspektívája nem a társadalomra, hanem a társadalom környezetére, illetve társadalomnak és környezetének a kölcsönhatására irányította a figyelmet. A környezetvédelem tehát olyan kérdést boncolgatott, ami távol állt a hagyományosan a társadalommal foglalkozó megközelítésektől, és ezért már kiindulásában is lényegesen új nézőpontot jelentett. A perspektíva újszerüsége magával hozta a megszokottól alapvetően különböző értelmezéseket is. A környezetvédelem azzal hívta fel magára a figyelmet, hogy először mutatott rá a környezetszennyezés ökológiai és társadalmi hatásaira: arra, hogy a társadalom nem szándékolt müködése úgy változtatja meg a környezetét, hogy ezáltal aláássa saját fennállása feltételeit is.

A környezetvédelem ennyiben nemcsak a biológiai környezet lerombolását mutatta be, hanem azt is, hogy azzal, hogy a társadalom hatással van a környezetére, egyúttal saját magát is veszélyezteti. A környezetvédelem kérdése ekképpen a környezetben történő visszafordíthatatlan folyamatokon túl a társadalom közelgő katasztrófáját is vizionálta. Ebből fakad, hogy az ökológiai mozgalmak a környezetszennyezés biológiai és társadalmi vonatkozásai miatt radikális beavatkozást sürgettek. A vizionált krízis elkerülése érdekében alapvetően új viszonyulást szerettek volna meghonosítani a környezet és a társadalom vonatkozásában is. Előbbi esetében a be nem avatkozás vagy a károk megszüntetésének politikáját javasolták, míg a társadalom esetében annak radikális megváltoztatását szerették volna elérni. Ennek részei voltak a politikai rendszer alapvető átalakítására tett erőfeszítések, az új környezetetika megfogalmazása és az állampolgárok környezettudatosságának erősítése (Lányi 2007). Mindez olyan szándékot takart, ami a társadalmi viszonyok újrarajzolását célozta meg, és szemben állt a társadalom korábbi irányítási és müködési mechanizmusaival. Nem véletlen tehát, hogy az ökológiai mozgalmak a társadalom müködésével szemben alapvetően elégedetlen, ún. protesztmozgalmak részeként mutatkoztak meg a társadalmi kommunikációban.

Az ökológiai kérdések ekképpen jellemzően a kritikai társadalmi mozgalmakban jelentek meg, és a tiltakozó mozgalmak establishmenttel szembeni küzdelmének részeként váltak láthatóvá a nyilvánosságban (vö. Fordulat 2019; illetve Antal 2014). Ez a pozíció jelölte ki társadalmi láthatóságukat. A protesztmozgalmak társadalmi helyzete határozta meg perspektívájukat és cselekvési stratégiájukat. Ennélfogva a mozgalmak radikális beavatkozást megcélzó politikája a társadalom intézményrendszerében és a döntéshozókban olyan tényezőket látott, amelyek a fennálló viszonyok továbbörökítésében voltak érdekeltek, és amelyek érzéketlennek mutatkoztak az ökológiai kérdések iránt. Mindez a már perspek- 
tívájában is radikális mozgalmak politikai radikalizálódásához vezetett: a mozgalmak az ökológiai veszélyekre hivatkozva a társadalom radikális átalakításának igényét fogalmazták meg. Kisebb részeredmények ellenére (egyes országokban a zöldpártok parlamenti képviseletet nyertek) a politikai áttörés elmaradt, így a radikális követelések érvényesítésére sem került sor. A több évtizedes jelenlét radikális változás helyett lassú módosulásokat eredményezett a környezeti kérdések megítélésében, de a társadalom rendszerszerű szerveződését nem alakította át.

$\mathrm{Az}$ ökológiai mozgalmak távlati terve a politikai rendszer alapvető átalakítása volt. $\mathrm{Az}$ establishmenttől függetlenül szerveződve nagy figyelmet fordítottak a civil társadalom megszólítására (Lányi 1994, 2012). A polgárok bevonásával igyekeztek megtörni a politikai intézményrendszer ellenállását. Fellépésükkel, a kérdések sajátos hangsúlyú megjelenítésével a krízis felismertetését szerették volna elérni, és ezáltal próbálták az embereket mozgósítani a környezetvédelem ügye és a társadalom radikális átalakítása mellett. A környezeti kérdések tudatosulását kívánták elérni, ami szerintük a politikai szándékaik könnyebb kivitelezését is eredményezné. (A két kérdés erősen összekapcsolódott az ökológiai mozgalmakban, hiszen - miként utaltam erre - az egyik mindig feltételezte a másikat: a radikális kérdésfeltevés és megoldási javaslat óhatatlanul radikális változást kívánt a társadalom intézményrendszerében.) Ezért olyan figyelemfelhívó akciókat szerveztek, amelyek szokatlanságukkal, radikalizmusukkal tüntek ki. Az akciók sikerességét a tömegmédiában való jelenlét ereje mutatta meg: minél nagyobb volt egy akció hírértéke, annál inkább képes volt felkelteni a közfigyelmet, és annál inkább kínált esélyt arra, hogy az emberek figyelmét odavonja.

Ez a helyzet és stratégia magyarázza az ökológiai mozgalmak tiltakozó akcióinak sajátos szerkezetét. A sokkolni próbáló akciók többnyire valami olyan aktuálisan fenyegető kérdést állítottak a középpontba, amellyel az embereket sikeresebben meg tudták szólítani. Vagyis a társadalmi sikeresség érdekében azokat az ökológiai problémákat, amelyekkel az állampolgárok személyes veszélyérzetére támaszkodva tudták a környezetvédelem szükségességére irányítani a figyelmet (Luhmann 1996b, 1996c, 1996d). A sokkolás célja a félelem felkeltése volt, ami szándékuk szerint a veszély tudatosulásán túl a tudati változást is elindíthatja. A félelem retorikája másfelöl összekapcsolódott a problémakör moralizálásával (Luhmann 1996b, 2010a; Karácsony 1987a). Az emberek felelősségérzetére tehát úgy apelláltak, hogy a megszólított civileket az etikailag helyes magatartásra képes személyekként tételezték.

A környezeti kérdéseket morális kérdésként bemutató perspektíva a társadalmilag kívánatos magatartás elmélyítését célozta meg. Mindez alapul szolgált a társadalom (morális) megújulására is, amelynek alapelveit az ekkor elszaporodó környezetetikák voltak hivatottak megfogalmazni. De az ökológiai mozgalmak morális retorikája nem csupán abból indult ki, hogy a környezetvédelem súlyának, jelentőségének és stratégiájának megítélése etikai alapon eldönthető, hanem a nem morálisan cselekvők felkutatására is alkalmat adott. A kérdés moralizálása ily módon a komplex kérdéskört több vonatkozásban is leszükítette a felelősök megtalálására (akik nyilvánvalóan a politikai, gazdasági establishment potentátjai voltak). Mindez egy olyan csoportosításhoz vezetett, amely a korrupt döntéshozókat az etikusan cselekvő, a társadalmat megőrző és a jövőt megjelenítő környezetvédőkkel állította szembe. 


\section{A társadalom rendszerelméleti leírása és az ökológiai mozgalmak nézőpontjának értelmezése}

Az ökológiai mozgalmak sikerességét, társadalmi hatását saját nézőpontjuktól lényegesen eltérő perspektívából értelmezem, amikor a rendszerelméleti megközelítés mellett horgonyzok le. A perspektívaváltást több szempont indokolja. Egyrészt úgy vélem, hogy ez a funkcionalista megközelítés adja a modern társadalom egyik legkomplexebb leírását, és ekképpen ez az ökológiai mozgalmak szerepének és lehetőségeinek jobb megértéséhez is közelebb vihet. Másrészt a zöldmozgalmak más szempontú értelmezése olyan jelenségekre is ráirányíthatja a figyelmet, amelyek e mozgalmak pozíciójából nem feltétlenül mutatkoznak meg. Ismeretelméleti belátásokból kiindulva úgy gondolom ugyanis, hogy minden társadalmi pozíció valóságértelmezésére hatással van az a nézőpont, ahonnan megrajzolja a valóságról alkotott képét. Ebből fakad, hogy minden helyzet mindig rendelkezik a maga „vakfoltjával”, tehát saját nézőpontjából bizonyos összefüggések nem láthatók (Luhmann 2009a, 1999a). A nézőpontváltás tehát azt ígéri, hogy ezáltal az ökológiai mozgalmak perspektívájának vakfoltjai is könnyebben felfejthetők lesznek.

A rendszerelméleti elemzés maga is egy radikálisan új perspektívát képvisel a társadalomelméleti irányzatok között (Luhmann 1991a, 1998a, 2005, 2009b; Rasch 2012; Jahraus 2012). A megközelítésnek az az alapja, hogy a megfigyelés perspektívája határozottan nem az individuumokra vagy az általuk alkotott közösségekre, társadalmakra fókuszál, hanem a társadalmat kommunikációkkal lezárt rendszernek tekinti (Luhmann 1981, 2009c; Karácsony 1990, 2000). A társadalmi jelenségek megragadásakor így a társadalmi rendszer értelmezésére, pontosabban a társadalmi rendszer és környezete differenciájának egységére fókuszál. Abból indul tehát ki, hogy a kommunikációk mentén megragadott társadalmi rendszer csak a környezetétől elkülönülve, de csak a környezetből jövő hatások („rendszerirritációk”) figyelembevételével írható le teljesebben (Luhmann 1995a). Vagyis a társadalom leírásakor nem az egyénekre, hanem azokra az „önreferenciális” (a társadalmi rendszer saját müködését biztosító) műveletekre összpontosít, amelyeken keresztül a társadalom, illetve a környezetével kapcsolatos kommunikáció megérthető.

Ebből a nézőpontból a társadalom ugyan saját műveletei mentén elkülönül a környezetétől (hiszen csak a társadalmon belül beszélhetünk kommunikációról), de a társadalom mint önreferenciális rendszer csak a környezetéből jövő külső hatások (irritációk) következtében hoz létre újabb struktúrákat (Luhmann 1999b). A társadalom környezetének ily módon fontos szerepe van a társadalmi folyamatok megrajzolásában. Társadalom és környezete másfelöl olyan struktúrákat alakít ki, amelyek saját müveleteik mentén figyelik meg önmagukat és a környezetüket. A társadalom mint kommunikációkkal működő rendszer önmegfigyelése, a környezet sajátos (biológiai, pszichikai) rendszereinek önmegfigyelése és egymás tevékenységének értelmezése jelenti azt a meglehetősen komplex viszonyrendszert, amelyben a jelenségek értelmezhetők. Az összefüggések meglátását nehezíti, hogy e rendszerek megragadása egy megfigyelői pozíciót feltételez (Luhmann 1999a; Éber 2009). Társadalom és környezetének kapcsolata tehát csak úgy hozható érvényesebben felszínre, ha másodlagos megfigyelöként az önmagukat megfigyelö rendszerek megfigyelésére vállalkozunk. 
A társadalom leírásának e nehézségei teszik óvatosabbá az elemzőt a hangzatos, de talán túlságosan leegyszerüsítő helyzetértelmezésekkel szemben (Luhmann 1996c, 1996d). A társadalom és környezetének strukturális kapcsolódásai jóval bonyolultabbak annál, hogy annak jegyei a tömegmédia csatornáin sokkoló és moralizáló üzenetekként leírhatók lennének. Gondoljunk itt csak a környezeti károkra és leírásukra. A rendszer és környezetének megfigyelése komplex (és jellemzően nem lineáris) kauzális összefüggések megragadására kínál lehetőséget, miközben azt is tekintetbe kell venni, hogy az érintett rendszerek (a társadalom és annak részrendszerei, például a gazdaság, a politika stb.) maguk is közrejátszanak ama tényezők létrejöttében, amelyek károkat váltanak ki bennük. Mindezek figyelembevétele már eleve megóvhat bennünket attól, hogy a környezeti veszélyeket a bünös és áldozat leegyszerüsítő sémája mentén értelmezzük. Nem vitatjuk el természetesen azt, hogy a társadalmi ranglétrán betöltött pozíció különböző szintű érintettséget jelent a döntéshozatali folyamatokban, de a jelenségek komplexebb értelmezése több dimenzió bevonását igényli. A kérdéskör moralizálása ugyan képes a figyelem felhívására, arra, hogy a megszólítottak állást foglaljanak, de a jelenségek megragadására bizonyosan nem elégséges.

Úgy látom, a funkcionalista nézőpont az ökológiai mozgalmak sajátos társadalmi pozíciójának és az ebből következő perspektívának a megvilágítására is lehetőséget kínál. Tiltakozásaik alapja nyilvánvalóan az, hogy képviselőik alapvetően csalódtak a társadalom működésében, és azzal szemben radikálisan más alternatívát kínálnak. Olyan igazságokat, amelyek nézőpontjuk szerint évszázadok felelőtlen, a döntéshozók alkalmatlanságáról tanúbizonyságot tevő gyakorlatával szemben a társadalmi viszonyok újrarendezését ígérik. Azután az ökológiai mozgalmak határozott, esetenként sarkos kijelentései olyan pozíciót sejtetnek, ahonnan a társadalmi jelenségek a maguk teljességében megragadhatók lennének. A zöldmozgalmak tagjai a társadalom átfogó bírálatához egy „társadalmon kívüli” pozíciót foglalnak el (Luhmann 1989, 1996e), innen mutatnak rá a társadalom rossz müködésére és innen küldik az általuk megváltónak hitt üzeneteiket.

Társadalomelméletileg ez a nézőpont a jórészt Marxszal induló kritikai iskolák perspektíváját jelenti. Ez a modern társadalmat úgy láttatja, mint amelyet a hatalmi viszonyok tartanak össze, és amely a társadalmi egyenlőtlenségeket fenntartani akarók érdekeiből fakadóan az igazság elfedésére rendezkedett be. Az ezzel szembenálló és a társadalmi viszonyokat átlátó kevesek pedig a valóság helyes ismeretével felvértezve küzdenek az elnyomó jellegü hatalommal szemben, és képviselik azt a helyes szemléletet, amely csak a fennálló rend radikális megváltoztatásával valósítható meg. Ez a megközelítés jelöli ki a társadalom megragadásának szemléletét és magától értetődően annak vakfoltjait is.

Ez a perspektíva - pozíciójából adódóan - a modern társadalom bonyolult szövetéből elsősorban csak azokra az összefüggésekre összpontosít, amelyek a hatalmi viszonyokat és belőlük fakadó társadalmi egyenlőtlenségeket megjelenítik. Nem vitatható, hogy ez a perspektíva a modernitás fontos jegyeit hozza felszínre, és elmélyítheti a tudásunkat a társadalmi egyenlőtlenségek természetéről. Ez a nézőpont azonban kevéssé érzékeny annak az évszázados társadalmi átalakulásnak a megragadására, amely a rendi társadalomtól lényegesen eltérő berendezkedést hozott létre (Luhmann 1977a, 1993a). E transzformációnak talán a leglényegesebb jegye, hogy a társadalom felépülése megváltozik: míg korábban egy hatalmi központból irányították a társadalom szerveződését, addig az újkortól kezdve (éppen az egyre komplexebbé váló viszonyok miatt) a társadalom fokozatosan egymástól független részterületekre bomlik, melyek autonóm logikájuk mentén szervezik meg saját kommuni- 
kációjukat és alakítanak ki kapcsolatokat a társadalom egyéb részterületeivel. Közös azonban bennük (legyen szó a gazdaság, a politika, az oktatás, a tudomány, a mủvészet stb. saját részterületeiről), hogy mindegyik a saját racionalitása mentén kommunikál a társadalom egyéb részeivel.

A jelzett változások alapvetően újjászervezik a társadalom szerkezetét. A rendi társadalom egyközpontú, monokontextuális kommunikációját felváltja a modern társadalom polikontextuális, sok önálló területtel szervezett kommunikációja. Mindez nem csupán a társadalom egyre komplexebb rendszerét eredményezi, hanem azt is, hogy a társadalom szerveződésének le kell mondania egy mindent meghatározó centrum tételezéséről, ami pedig óhatatlanul azt vonja maga után, hogy a modern társadalom nem rendelkezik azzal a pozícióval sem, ahonnan megfellebbezhetetlen igazságokat lehetne megfogalmazni. Ebből következően minden kommunikációnak helyi értéke van, és minden kommunikáció magán viseli azt a sajátos társadalmi pozíciót, amelyben megfogalmazódik. Magától értetődő így az is, hogy a modern társadalom e szerveződése nem tesz lehetővé olyan „társadalmon kívüli” pozíciót sem, amely mentes lenne a társadalmi viszonyrendszerektől, és ami igényt tarthatna a társadalom egészére vonatkozó „helyes” reflexió megfogalmazására. Nyilvánvalóan ez érvényes az ökológiai mozgalmak nézőpontjára is, mint minden olyan nézőpontra, amely saját perspektívája mentén reflektál a társadalmi viszonyokra, s ekképpen a társadalom sajátos önleírását adja. Mindez nem azt jelenti, hogy ez a perspektíva érvénytelen lenne, hanem csak azt, hogy osztozik a társadalom egyéb (például a tömegmédia, a szervezetek stb.) önleírásának viszonylagosságában.

Meglátásom szerint nagyban nehezíti az ökológiai mozgalmak társadalmi sikerességét, hogy ez az ismeretelméleti belátás zömében nem része a mozgalmat képviselők gondolkodásának. A saját társadalmi pozícióra való reflexió hiánya pedig olyan vakfoltot eredményez, amely nagyban nehezíti a környezetvédelem ügyét. Az igazság birtokosaként fellépő mozgalmak - társadalomelméletileg nézve - egy korábbi történeti korszak, a monokontextualitással jellemezhető társadalmak szemantikáját képviselve indulnak harcba a modern társadalom polikontextuálisan szerveződő viszonyai és intézményrendszere ellen. Ez a perspektíva magyarázza talán azt, hogy a környezetvédők gyakran ütköznek falakba, és őszinte lelkesedésük és tiszteletre méltó elkötelezettségük ellenére kis hatékonysággal tudnak csak változásokat elérni. Ennek legföbb oka az, hogy a modern társadalom lényegileg másképp felépült intézményrendszere kevés affinitást mutat a környezetvédelem nézőpontjának beemelésére. Megközelítésem szerint azonban itt elsősorban nem a hatalmon lévők arroganciája, gőgje mutatkozik meg (miként ezt a zöldmozgalom képviselői gyakran megfogalmazzák), hanem a modern társadalom rendszerszintü felépítése.

A modern társadalom autonóm részterületei ugyanis saját specifikus kommunikációjuk (például a gazdaságnak a rentabilitásra, a jognak a jogszerüségre, a művészetnek a szépre vonatkozó megkülönböztetése) mentén alakítják ki saját müködésüket és a társadalmat e szempontok mentén írják le. Minden egyes társadalmi részterület saját preferenciakódja mentén szelektál a társadalmi kommunikációból, és a kívülről jövő hatásokat is saját racionalitása mentén értelmezi. A társadalom más területeiről jövő környezeti ingerek ebben az értelemben elengedhetetlenek sikeres müködéséhez, másrészt azokat kizárólag saját belső működéséhez igazítva használja fel vagy utasítja el. Ez a sajátos elkülönülés és strukturális kapcsolódás alapozza meg az egyes részterületek autonómiáját, és ez teszi lehetővé azt, hogy a külső ingereket mint irritációkat értelmezze. A modern társadalom sajátossága, 
hogy ahány részrendszerrel rendelkezik, annyiféle rezonanciát keltenek benne az ökológiai mozgalmak által megfogalmazott javaslatok, követelések. Mindegyik területe reflektál ekképpen az ökológiai kihívásra, illetve az ezt megjelenítő mozgalmak álláspontjára, azonban a reflexiók a részterületek saját strukturális meghatározottsága mentén értelmezik a kívülről jövő üzenetet. Ez pedig nyilvánvalóan kizárja, hogy a társadalom egységesen és a javaslatot megfogalmazó perspektíváját elfogadva (vagy azt egyáltalán mélyebben megértve) reagáljon a környezeti krízis jelentette kihívásra.

A rezonanciák megsokszorozódása tehát nem hoz létre egy olyan kitüntetett pontot, ahonnan a társadalom (helyesen, kívánatosan) reagálhatna az ökológiai mozgalmak fellépésére. Az egyes részrendszerek autopoiétikus, tehát saját műveleteiből felépülő struktúrája ráadásul saját racionalitása szerint működik minden esetben. Ez nemcsak belső autonómiát eredményez, hanem óhatatlanul azt is, hogy az egyes részterületek (gazdaság, jog, politika, oktatás stb.) csak olyan külső ingereket tudnak a belső müködésükbe integrálni, amelyek illeszkednek a részrendszer eddigi müködéséhez. Vagyis a modern társadalom részrendszerei nem arra vannak kondicionálva, hogy radikális változtatásokra reagálni tudjanak. Ez ugyanis ellentmondana az eddigi müködésük során kialakított szerkezetüknek és veszélyeztetné az egyes részterületek működését.

A részrendszerek csak saját racionalitásuk mentén tudnak „gondolkodni”. Ez azt is jelenti, hogy a modern társadalom részrendszerei érzéketlenek a saját megkülönböztetésüktől eltérő, külső szempontokra, illetve azokkal csak akkor tudnak valamit kezdeni, ha a saját racionalitásuk számára értelmezhető üzenetté formálják őket. Hiába állunk elő tehát azzal az ökológiai szempontból felettébb releváns megjegyzéssel, hogy a környezeti veszélyek az egész társadalom működését veszélyeztetik. A részrendszerek bináris kódjai (a jog esetében jogszerű vagy jogszerűtlen, a gazdaság esetében rentábilis vagy nem rentábilis, a művészet esetében szép vagy nem szép) a morálon kívüli megkülönböztetéssel operálnak. Nem tudnak arra érdemi reakciót adni, ha saját racionalitásuktól független szempontokat kellene figyelembe venniük, akármilyen veszélyt is jelentsen ez a társadalom egészének megmaradására. Szelektálni és mérlegelni tehát csak saját rekurzív (korábbi tapasztalataira visszautaló) kommunikációs szerkezetük mentén képesek. Ez határozza meg saját autonómiájukat és működésükett.

Ennyiben a részrendszerek autopoiézisének következő lépése a maguk számára mindig fontosabb, mint a jövő figyelembevétele. Ez magyarázza azt a - sokak számára nehezen feldolgozható - összefüggést, hogy az ökológiai önveszélyeztetés evolúciós szempontból reális lehetőség. Vagyis a modern társadalom egyik sajátossága, hogy képes olyan módon hatni a környezetére, hogy később nem lesz képes ebben a környezetben létezni (Luhmann 2010b). A társadalom müködése tehát (és határozottan nem a társadalomban megfogalmazódó ideológiák!) nem ismer olyan teleológiát, amely kizárná azt, hogy a társadalom saját működése felszámolja önmagát.

\section{A modern társadalom részrendszerei és az ökológiai kommunikáció}

Az ökológiai mozgalmak által megfogalmazott környezeti veszélyek tehát lényegesen másképp jelennek meg a protesztmozgalmak képviselőinek és az egyes társadalmi részterületeknek a perspektívájában. Elemzésem arra szeretné ráirányítani a figyelmet, hogy ennek 
alapvetően strukturális okai vannak. A zöldmozgalmak által képviselt kétségtelenül fontos üzenetek a részrendszerek saját racionalitásain keresztül jelennek meg azok kommunikációjában. A két perspektíva sokszor ellentétes helyzetértelmezése és cselekvési stratégiája is a strukturális összefüggések felfejtésén keresztül ragadható meg jobban. Talán közelebb kerülhetünk az ökológiai megközelítés lehetséges hatásainak megértéséhez, ha röviden áttekintjük, hogy a modern társadalom legfontosabb részrendszerei miképpen értelmezik a környezeti veszélyekről szóló üzeneteket.

Tartózkodnék ugyan attól a némileg rövidre záró állásponttól, amely a modern társadalmat kizárólag a gazdaság által meghatározottnak tekinti, és minden társadalmi problémát a gazdasági egyenlőtlenségre és úgy általában a kapitalizmus logikájára vezet vissza, de kétségtelenül a gazdaság a modernitás egyik legnagyobb súlyú részrendszere (Luhmann 1998b). Azonban a gazdaság sem különbözik a társadalom egyéb részterületeitől annyiban, hogy a gazdaságot is a saját racionalitása, saját bináris kódja alapján szelektáló kommunikációja határozza meg. Ez biztosítja azt az autonómiát, amely a gazdasági rendszer saját idejében és dinamikájában is megmutatkozik. Ez eredményezi korlátos érdeklődését az ökológiai veszélyek iránt. A környezetvédelem felöl jövő külső irritációra, minden más külső hatáshoz hasonlóan, csak akkor képes rezonálni, ha az beépíthető saját racionalitásába, saját piaci körforgásába. Úgy is fogalmazhatnánk, hogy az ökológiai problémák kulcsa az árak nyelvében rejlik: a gazdaság nem képes reagálni azokra a zavarokra, amelyek nem fejezhetők ki ezen a nyelven (Luhmann 2010a: 65-77).

Ebből fakadóan nem várható az, hogy a gazdaság müködése a környezettudatosság elsődleges szempontja alapján történjen, de saját szelekciója mentén képes reagálni a környezeti kihívásra. A gazdaság pillanatnyi szelekciójában² akkor mutatkozik nyitottnak a környezeti problémákra, ha azáltal új profitlehetőséget, új piacokat találhat. Ha nem is lehetséges, hogy gazdaságon kívüli (mondjuk etikai) szempontok alapján a gazdaság a környezetvédelem szempontjait érvényesítse, de az ökológiai szempontok olyan új profitlehetőségeket nyújthatnak, amelyekhez a gazdasági rendszer is megtalálja a kapcsolódásokat. Vagyis a gazdasági viselkedés módosítható ökológiailag kívánatos módon, például azáltal, ha a fogyasztók hajlandók többet fizetni a nagyobb költséggel előállított, ezért drágább, de mégis környezetkímélőbb termékekért, vagy környezettudatos megfontolásból nem a kisebb költséggel készült, ezért olcsóbb, ámde környezetkárosító termékeket vásárolják meg. A gazdasági rendszer saját racionalitása azonban nemcsak abban mutatkozik meg, hogy a környezeti szempontok számára kedvezően reagálhat a környezeti kihívásokra, hanem abban is, hogy olyan termékeket (például nagyobb teljesítményű légkondicionálókat, hűtőrendszereket) kezdenek piacra dobni, amelyek csak a nagyobb vásárlóerővel rendelkezők számára segítenek elviselni a megváltozott klíma okozta nehézségeket. Ekkor a gazdaság nem a környezeti károk mérséklésében látja meg a piaci lehetőségeket, hanem azokat adottságként elfogadva újabb piacokat épít ki magának.

Hasonlóan korlátozott a jogrendszer affinitása is az ökológiai kommunikáció által megfogalmazott kérdésekre. A környezetvédők részéről ugyan gyakran megfogalmazódik, hogy a jogi eljárásokban az igazságosságot és méltányosságot kellene képviselni, de a modern jog-

2 Feltehetően egészen más szelekciós mechanizmus alakulna ki, ha egy ökológiai katasztrófa alapjában rengetné meg a gazdaság mostani müködését. Ez esetben ugyanis a katasztrófának már struktúraképző ereje lenne, az beépülne a gazdasági rendszer rekurzív struktúrájába, és az új szelekció már ezt a tényezőt is figyelembe véve alakítaná ki a kommunikációit. Ez a belátás azonban kevéssé használható a jelen pillanatban. 
rendszer határozottan nem erre szerveződött. A jog részterületének illetékessége kizárólag a jogszerü és jogszerütlen megkülönböztetésére korlátozódik (Luhmann 1995b). Ennek megítélése határozza meg a jogi döntéseket, és a jog egész intézményrendszere ennek érvényesülését biztosítja. Másfelöl egy jelenbeli jogi döntés visszatükrözi a jog történeti kiválásának és a jogszerüség alapján történő eljárásoknak hosszú történeti hagyományát is (Karácsony 1987b). (Még azokban az országokban is, ahol nem a precedensjog érvényesül.) Ez a forrása a jelenbeli jogi döntéseknek, és ebből következik az eddigi jogi eseteken kikristályosodó jogrend sajátossága: csak a meglévő jogrend talaján tud reagálni a környezeti hatásokra. Ez biztosítja kapcsolódási képességét saját hagyományához és a társadalom többi részterületéhez (a gazdasághoz, a politikához stb.) is, és ez csökkenti az affinitását azon ökológiai veszélyek iránt, amelyek kevéssé vagy egyáltalán nem kapcsolódnak a jogrend meglévő szelekciójához.

A jog kapcsolódási képességét ezenfelül az is korlátozza, hogy a jog a szociális viszonyok szabályozására hivatott, a környezeti mozgalmak pedig olyan fizikai, kémiai és biológiai kérdéseket vetnek fel, amelyekre a jog kevéssé felkészült: vagyis a természet esetében mintha kevéssé müködne a természetjog. A jogi gondolkodás alapvető formái tehát a jogi rendszerben a szociális rendre való törekvést képviselik. Ennek gyakorlata azt jelenti, hogy egy jövőbeli múlt képzete alapján hagyják a dolgokat megtörténni, és csak azt írják elö, miképpen kell kezelni, ha e dolgok bekövetkeznek. Ez az eljárás az alapja a jogi szabályozásnak. Az ökológiai szempontok ebben a viszonyrendszerben értelemszerüen csak jogi formában jelenhetnek meg, hiszen a jogrend csak a jogszerü-jogszerütlen megkülönböztetés alapján megfogalmazott javaslatokkal tud mit kezdeni (Luhmann 2010a: 78-92).

A jogi kérdésekhez radikálisan másképp nyúló környezeti jognak tehát ehhez a gyakorlathoz kell(ene) alkalmazkodnia, ${ }^{3}$ különben csak a jog müködésére nézve hatástalan irritációkat tud megfogalmazni. A környezeti jog elképzelései mindaddig csak problémákra vonatkozó ideák lesznek, amíg a jogrend hagyományához is illeszkedve nem tudnak új jogi szabályozásokat kieszközölni. Ez azonban nemcsak a környezeti jog radikálisan más értékrendje miatt nehezen kivitelezhető, hanem a környezeti mozgalmak által követelt, a környezettudatosságot jobban megjelenítő toleranciahatárok megállapításának problémája miatt is. Itt éppen az a konszenzus hiányzik, amire a racionális vita vonatkozásában (vö. Habermas 2011) oly nagy előszeretettel hivatkoznak a mozgalom résztvevői. Mivel a kockázati tényezők megítélésében még a tudomány sem egységes, illetve a kockázati hajlandóság is felettébb különböző az érintettek körében, így például a szennyező, mérgező anyagok, gázok határértékeinek megállapításában nem támaszkodhatnak konszenzusra, hanem csak valami önkényes szabályozást érvényesíthetnek. Ezenkívül kihívást jelent az is, hogy a környezeti tényezőként aposztrofált összefüggések a társadalom legkülönbözőbb területein bukkanhatnak fel, és sokszor átláthatatlan módon vannak jelen. Ez nem csupán a jogi szabályozást teszi nehézzé, hanem azt is, hogy konszenzus alakulhasson ki a szabályozás területein és tartalmában.

Kevés megerősítést kaphat az ökológiai kommunikáció a modern társadalom egykor nagyobb súllyal rendelkező, de mára már kisebb hatású részterületeitől, a tudománytól és a vallástól. A tudomány ugyan saját kommunikációjában az igazság megismerésére szerveződött és ekképp komoly elméleti munícióul szolgálhatna a környezeti mozgalmak számára a

3 A környezeti szempontok partikuláris jelenlétét és jogi érvényesülésének korlátait elemzi if. Zlinszky János a magyar alkotmány vonatkozó passzusaiban (Zlinszky 2001). 
ránk leselkedő veszélyek bemutatásával, de sajátos szerveződése kevéssé teljesítheti ezeket az elvárásokat. Ugyan a jelenségek komplex vizsgálatai egyre inkább olyan többváltozós elemzésekkel dolgoznak, amelyek egyre több tényezöt tudnak az elemzésbe bevonni és válnak ezáltal képessé arra, hogy összefüggéseket teremtsenek az egyes dimenziók között, ${ }^{4}$ de azok a különböző elméleti perspektívákat tükröző kutatói döntések, amelyek a kutatás számára releváns dimenziókat vonnak be vagy negligálnak az elemzésben, óhatatlanul eltérő eredményekhez vezetnek ugyanannak a kérdésnek a vizsgálatakor is.

Mindez éppen annak a konszenzusnak és biztos tudásnak az esélyét veszi el, amivel az ökológiai mozgalmak - immár a tudomány autoritásával felvértezve - meggyőzőbben érvelhetnének saját perspektívájuk fontossága mellett. Ennek hiányában azonban mindenki (a környezetvédők és az establishment tagjai is) csak azokat a tudományos eredményeket szajkózza, amelyek álláspontjukat aktuálisan megerősítik anélkül, hogy a tudományos igazságok döntő érvek lehetnének egy vitában. És itt még nem is említettük azt a problémát, hogy a tudományos belátások milyen feltételek mentén találnak meglehetősen szükösen utat a többi társadalmi részrendszer (gazdaság, jog, politika stb.) kommunikációjához, és menynyire esetleges a tudományos igazságok össztársadalmi érvényesülése (Luhmann 1990). ${ }^{5}$

A környezetkárosítás következményei a társadalom mellett magukat az egyéneket is veszélyeztetik, s ennyiben egzisztenciális kérdéseket is felvetnek. Mindez azt eredményezi, hogy fokozódik a létre irányuló reflexió és szükségesé válik az értékekhez füződő viszony tisztázása. Olyan kérdések ezek, amelyek esetében a vallás hosszú ideig meghatározóan irányt mutatott. A modern társadalomban ugyan nem tünt el a vallási kommunikáció és a transzcendensre való reflexió, de a vallásilag megalapozott kozmológia kétségtelenül háttérbe szorult (Luhmann 1977b, 2000; Taylor 2007; Storm 2009). A közéleti diskurzus szekularizálódása, a hit és a vallásgyakorlás csökkenése és annak a kulturális kondíciónak az elterjedése, hogy a vallástalan nézőpont preferált vagy többségi állásponttá vált a társadalomban (Taylor 2007), mind olyan tényezők, amelyek nagyban szükítik az esélyét annak, hogy a vallási üzenetekben általában (és különösen a zsidó-keresztény hagyományban hangsúlyozottan) jelenlévő etikai szempontok erősíthessék az ökológiai mozgalmak érvelését. Ehhez az is hozzájárul, hogy a magukat vallásosnak nevezők értékpreferenciái is egyre inkább elszakadnak saját vallási hagyományuktól és egyre inkább a szekularizált társadalom értékeihez illeszkednek (Scheepers, Gijsberts és Hello 2002; Botvar 2005; Finke és Adamczyk 2008; Storm 2016). Mindez azt eredményezi, hogy a vallás kevés sikerrel tud hozzájárulni a környezeti veszélyek társadalmi rezonanciájához. ${ }^{6}$

A környezeti mozgalmak részéről - és a közéletben általában is - a legtöbb elvárás a politikával kapcsolatban fogalmazódik meg. A követelések gyors és radikális változások meghozataláról szólnak, és leggyakrabban azt a hitet tükrözik, hogy a politika képes a társadalmi viszonyok alapvető újrarendezésére. Mindehhez látszólag nem szükséges egyéb, csak kellő

4 Gondoljunk csak arra, hogy a társadalomtudományos kutatás gyakorlatában hova jutottunk a pár évtizeddel ezelőtti két-, háromdimenziós kereszttábláktól és faktoranalízisektől a mostani kutatások SEM-modelljéig.

5 Utóbbi problémára utal Vida Gábor elemzése is, amikor bemutatja, hogy a környezetszennyezéssel kapcsolatos, a tudományos körökben megkérdőjelezhetetlen igazságok is mennyire nehezen találnak utat a többi részrendszerhez (Vida 2016).

6 Vallás és ökológia szerepének lényeges átpozicionálódását jelzi, hogy napjaink egyik jelentős vallásszociológusa már nem azzal a kérdéssel foglalkozik, hogy a vallás mennyiben tudja formálni az ökológiai gondolkodást, hanem azt boncolgatja, hogy vallás lett-e a környezetvédelem (Joas 2019). 
bátorság és a társadalom valódi értékeinek, érdekeinek a képviselete. Ezt az inkább ideológiai víziót, mintsem megalapozott társadalomelméletet azonban sem a modernitás eddigi története, sem a társadalom érvényesebb leírása nem igazolta. A modern társadalom jóval komplexebb annál, hogy bármely részterülete a társadalom csúcsa, központi instanciája lehetne. Ez érvényes a mindenki számára kötelezö érvényü döntések biztosítására szolgáló politika területére is (Luhmann 2002a). A modern politika kormányra és ellenzékre tagolódó rendszere a pozíciókat birtoklók, hatalommal rendelkezők és a hatalommal nem rendelkezők, de választási alternatívát jelentőkre tagolódik. Az ez alapján müködő váltógazdaság saját racionalitása mentén igyekszik választ adni minden, a rendszerben felmerülő problémára a munkanélküliség kérdésétől a szociális juttatásokon keresztül az adózásig. Az ökológiai kérdések ekképpen a politikai rendszer univerzalitása számára a felsorolhatatlanul sok fontosnak ítélt kérdés egyikeként jelennek meg. Mindez már kijelöli azt, hogy mennyiben képes a politika az ökológiai kérdések megoldására fókuszálni.

A környezetvédők által várt radikalizmus különleges státuszt, a politikai döntéshozatalban a környezetvédelmet középpontba állító stratégiát vár el (Fordulat 2019). A politika pillanatnyi müködésképességét azonban az biztosítja, hogy a társadalom részéröl rátestált funkció, a mindenki számára kötelező érvényü döntések meghozatala tekintetében megőrizzen egy viszonylagos egyensúlyt, és másrészt a korábbi döntései mentén (ennyiben is a status quót és nem a radikális változást erősítve) egyensúlyozzon a lényegesnek ítélt kérdések között. Mindez már önmagában felettébb valószínütlenné teszi, hogy a politikai rendszer a meglévőtől határozottabban eltérő politikát vagy környezetpolitikát képviseljen (Luhmann 2010a: 103-112). Az ökológiai kommunikáció hangsúlyosabb jelenlétének esélyét rontja az is, hogy a modern politikai rendszer demokratizmusa miatt ráutalt a politikai irányvonal sűrű változására. A jellemzően négyévenként történő választások pedig azokat a kérdéseket állítják a középpontba, amelyek rövidebb időintervallumban orvosolhatók (a foglalkoztatás kérdései, a szociális juttatások növelése stb.), és a választópolgárok pillanatnyi preferenciáit fejezik ki. Mindez nem kedvez azoknak a kérdésköröknek, amelyek csak hosszabb időszakban és tartós figyelem- és forrásráfordítással orvosolhatók. Az ökológia azonban éppen ezek közé a kérdések közé tartozik, és feltehetően a fenti tényezőkkel is magyarázható, hogy a több mint három évtizedes, parlamenti képviselettel is rendelkező európai ökopolitika (Ohnsorge, Kajner és Ungvári 2005; Boda és Scheiring 2006), kisebb részeredményeken túl, nem volt képes lényegi hatást gyakorolni a politikai rendszer müködésére.

Mindez nem jelenti azt, hogy a politika területén nem lenne mozgástere a környezetvédelemnek. A kérdés tartós közéleti tematizálása, a civil társadalom környezetvédő csoportjainak jelenléte a tömegmédiában, az oktatásban és a későbbiekben taglalt értékváltozások a társadalomban mind olyan tényezők, amelyek képesek hangsúlyeltolódásokat eredményezni a politikai rendszerben artikulált kérdések tekintetében. Úgy is fogalmazhatnánk, hogy a rendszer kommunikációja bővíthető ökológiailag fogékonyabb politikával, még ha az elözőek értelmében a politikai rendszer univerzalitása korlátos lehetőségeket kínál az ökológiai kérdések hangsúlyos taglalására. Jelentősebb változás akkor érhető el, ha a környezeti mozgalmak, a tömegmédia és az oktatás által leginkább hangsúlyozott környezetvédelem képes olyan nyomást gyakorolni a politika rendszerére, hogy a környezetvédelem ügye be tudjon kerülni a választások aktuális kérdései közé, mint olyan téma, amelynek megoldatlansága aktuálisan ránk leselkedő veszélyt tartalmaz, és mint ilyen, ciklusokon függetlenül hangsúlyos kérdésként kell megjelennie. Egy ilyen „rendszerirritáció” olyan strukturális változást 
eredményezhet a politikában, hogy párttól és ideológiai platformtól függetlenül kiemelt kérdéssé formálná a politikai elit számára is a környezetvédelem ügyét.

Az oktatás területének müködése is magán viseli saját racionalitását, és a környezetvédelem kérdéséhez saját preferenciája mentén viszonyul. Ez a régmúltig visszanyúló és a jelenig tartó idősíkban folyamatosan aktualizálódó tudáskészlet képezi ennek a részterületnek az autonómiáját. A társadalmilag releváns tudás elsajátítására szerveződő részterület müködése másrészt akkor sikeres, ha saját önálló működése folyamatosan impulzust kap a többi részrendszertől, hiszen ezek a kívülről jövő hatások biztosítják a strukturális kapcsolódásokat a többi részrendszerhez: ez teszi lehetővé azt, hogy az oktatási rendszer a többi társadalmi terület számára releváns ismereteket közvetítsen (Luhmann 2002b). Ebből fakad, hogy az oktatási rendszer a többi részterület eddigi müködése során fontosnak ítélt tudás közvetítésére törekszik, miközben saját autonóm müködése által is meghatározott. (Emiatt az oktatás nem mindig jeleníti meg a részrendszerek aktuális elvárásait, hanem sokszor a saját hol dinamikusabb, hol lassabban reagáló struktúrája jelöli ki az oktatás tartalmait.) A környezetvédelem ügye ezeken a strukturális kapcsolódásokon keresztül tud megjelenni. Tekintettel arra, hogy az ökológia közvetlenül egyik részrendszer kommunikációjában sem lényeges tényezö, az oktatási rendszer sem kezeli fontos kérdésként. Ez határozza meg azt, hogy az oktatási rendszer is - ugyan a korábbi időszakhoz mérten növekvő súllyal, de - csak periferikusan jeleníti meg a környezetvédelem kérdését a társadalmi kommunikációban.

Az oktatási rendszer tartalmának tehát kapcsolódóképesnek kell lennie a többi részrendszerhez, és ez a müködési sajátosság korlátozott mozgásteret biztosít a környezeti kérdések tematizálására. Az oktatási rendszer azonban mégis teret enged a környezetvédelem ügyének, mivel a rendszer dinamikus változása miatt a fiatalabb generációk mindig nagyobb nyitottságot mutatnak az újabb társadalmi problémák iránt. A rendszer tehát sajátos kettősséggel működik. Egyfelöl a többi részrendszer és saját múltbeli müködése által meghatározott, másfelöl pedig a folyamatosan változó feltételekre reagáló, ekképpen dinamizmussal is jellemezhető rendszer olyan generációk oktatására szerveződik, amelyek maguk is a változás (a „másnak kell lenni, mint a korábbiak” imperativusa) által meghatározottak. Ebből következik az, hogy ha a civil mozgalmak és a tömegmédia képessé vált a környezetvédelem kérdését új és fontos kérdéssé formálni, akkor az ifjúság ehhez az üzenethez már kapcsolódni tud és maga is elköteleződhet a környezetvédelem ügye mellett. Ez pedig esélyt kínál arra, hogy a környezeti szempontok, ha nem is a protesztmozgalmak által követelt radikalizmussal, de minden részrendszer kommunikációjában fontos tényezőként megjelenhessenek. A jelenlegi nyugat-európai és észak-amerikai helyzet immár erről a gyakorlatról tanúskodik.

Ennek az optimizmusra okot adó társadalmi változásnak is megvannak azonban a korlátai. A fiatal generációk nyitottsága az újabb kérdések iránt, a megváltozott problémaérzékenység egyaránt az oktatási rendszer említett jegyeinek és az életkori jellemzőknek a függvénye. Emellett azt is érdemes figyelembe venni, hogy az oktatási rendszer az egyének viszonylatában a társadalmilag releváns tudást karrierlehetőségként közvetíti. Az egyének tehát az onnan jövő impulzusokat elsősorban egyéni mobilitási lehetőségeik mentén értelmezik. Ebből értelemszerüen következik, hogy azoknak a tudásoknak lesz nagyobb jelentőségük, amelyek sikerrel kecsegtetnek a karrieresélyek megvalósításában. A jelenlegi állás szerint erősen kérdéses, hogy a környezetvédelem a stabilan jelenlévő, erősen identitást formáló tudások közé sorolható-e, vagy inkább olyan ismereteket jelent csak, amelyek az életkor változásával veszítenek a jelentőségükből. (Az értékszociológiai vizsgálatok e tekin- 
tetben csak kevés támpontot adnak [például Inglehart, Basanez és Moreno 1998], mivel a társadalomban enyhén növekvő környezettudatosságról ugyan vannak már kutatások, de azok még nem fókuszálnak olyan longitudinális vizsgálatokra, amelyek megmutathatnák, hogy az életkor haladásával a környezetvédelem ügye - adott korcsoporton belül - megőrzi-e a jelentőségét vagy veszít abból.)

A környezetvédelem kérdése és a társadalmi részrendszerek viszonya tehát meglehetősen komplex kapcsolatot mutat. Az egyes részrendszerek preferenciakódjuk, racionalitásuk mentén némileg eltérő viszonyt alakítanak ki az ökológiai kérdésfeltevésekkel kapcsolatban, de azokat egyaránt olyan külső tényezőkként értelmezik, amelyek irritációja csak kevéssé tudja formálni saját müködését. Mégsem arról van szó, hogy a modern társadalom ne rezonálna a környezeti szempontokra. Ezt a reakciót sokkal inkább az jellemzi, hogy a társadalom részrendszerei egyszerre (túl) sok, de mégis túl kevés, vagyis kevés hatással rendelkező impulzust kapnak (Luhmann 2010a: 134-139). Az ökológiai kommunikáció tehát sokszorosan van jelen a társadalmi kommunikációban, de ez a mindenhol jelenlét csak lassan tud változást eredményezni a részrendszerek müködésében. Nem véletlen tehát, hogy az ökológiai mozgalmak hol tudatos, hol nem tudatos válasza erre a frusztráló helyzetre általában a morális kommunikáció erősítése lesz. Az eleve moralizáló diskurzus tehát még inkább hangsúlyozza az etikai szempontú értékeléseket, és még inkább jellemző lesz rá az elismerés-megvetés alapján való tájékozódás. Ennek része lesz a politikai vezetők nyilvános megbélyegzése, és általában azok az akciók, amelyek leginkább a „korrupt, rövidlátó, felvilágosulatlan” döntéshozók nyakába varrják a környezetszennyezés problémáját, vagy úgy láttatják, hogy az ő meggyőzésükkel számottevően javítani lehetne a környezetvédelem helyzetén. Az ilyen akciókat sokszor olyan eszköznek tekintik, amely képesek áttörést eredményezni és a környezeti értékeknek radikálisan nagyobb súlyt kölcsönözni. A továbbiakban azt tekintem át, hogy ennek a környezeti mozgalmak részéről érthető stratégiának milyen korlátai és lehetőségei vannak.

\section{A környezeti mozgalmak morális kommunikációjának lehetőségei és korlátai}

Nem vitatható, hogy a kommunikáció morális kódolása jelentős integratív funkcióval rendelkezik. A morális kommunikáció elismerésre és megvetésre bomló megkülönböztetése ugyanis minden társadalmi cselekvő számára világossá teszi, hogy melyek azok a cselekvési minták, amelyeket a közösség elutasít, és melyek azok, amelyeket engedélyez (Parsons 1949; Joas 2002; Luhmann 2008a). A morális kommunikáció további sajátossága, hogy magával vonja a normaképződést, aminek eredményeképpen a morális mint jó és szokásos jelenik meg. Ezek azok a jegyek, amelyekre rendszerint a környezetvédők is hivatkoznak, amikor az ökológiai kérdések moralizálásával a mindenki számára kívánatos cselekvéseket szeretnék megfogalmazni. Vagyis a moralitásra hivatkozás egy olyan értékkonszenzust igyekszik kommunikálni, amellyel a környezetvédelemben és általában a közéleti kérdések területén is világos és egyértelmű válaszokat kaphatunk: lehet, hogy a társadalom szövete egyre bonyolultabb lett, de a morális értékelés egyértelmüséget ígér (Lányi és Jávor 2005; Lányi 2010a, 2015).

A környezetvédők ezen okfejtése tehát a fentiek vonatkozásában megalapozott társadalomelmélettel rendelkezik. Azonban kevéssé veszi számba azt, hogy a morál nem csupán egy a további kommunikációt segítő konszenzust fejezhet ki, hanem annak ellenkezőjét is. 
Ez következik be, amikor a morál tartalmának megítélésében viták alakulnak ki. Ezen a ponton pedig a morál reflexívvé válik, vagyis a kialakulásával együtt a tagadása vagy a benne való kételkedés is megjelenik (Luhmann 2008b). Ebben a vonatkozásban a morális kommunikáció éppen nem az integráció lehetőségét növeli meg, hanem a társadalmon belüli konfliktusét. Különösen a modern társadalom esetében, amelyben a jó és rossz sok, egymással versengő, a kommunikáció alapjául szolgáló megkülönböztetései egyaránt morális megalapozásra törekednek, ezzel pedig óhatatlanul a társadalmon belüli feszültségeket erősíti. Ebben az is szerepet játszik, hogy a morális kommunikáció a többi részrendszer racionalitásával szemben egy specifikáció nélküli univerzalizmust képvisel (Luhmann 2008c), és amikor univerzalisztikus igényét érvényesíteni akarja, konfliktust okoz a társadalom müködésében.

A morális kommunikáció tehát kettős természetű: egyfelől növelheti a konfliktust a társadalomban, másfelől azonban képes konszenzusépítésre és közös értékrend megalapozására is, ami adott esetben segítheti a környezeti mozgalmak érvelését. Társadalomtörténetileg szemlélve a morális kommunikáció sikeressége azonban leginkább a modern társadalomban kérdéses. A hierarchikus társadalmak alá-fölé rendeltségi, centrum és periféria viszonyai megkülönböztetésével operáló kommunikációjában nagyobb esély van arra, hogy meggyözően képviselhetők legyenek a morális elvek. A modernitás funkcionális tagozódása azonban erre csekély lehetőséget kínál. Ebben a társadalomban ugyanis az elvárások és a teljesítmények végképp kiszakadnak a morális ítélkezés elismerés-megvetés sémája alól, amenynyiben a kommunikációt nagyban az egyes részrendszerek sajátos racionalitása határozza meg (Luhmann 2008b). Mint többször utaltam rá, a modernitás beköszöntével a társadalom egyre bonyolultabb szövetét fokozatosan az egyes részterületek sajátos racionalitása határozza meg. Mindezek a területek (gazdaság, jog, politika, oktatás, tömegmédia stb.) ugyanis a saját autonómiájukat tükröző megkülönböztetésekkel az egésztől, az egységestől eltérő szerveződéseket, önreferenciális rendszereket hoznak létre.

Ezeknek a részrendszereknek az eltérő megkülönböztetései egységesek a tekintetben, hogy a morális tájékozódástól független bináris kóddal szabályozzák saját müveleteiket (Luhmann 2008d). A részrendszerekben a helyesség kritériumát csak meghatározott kódokhoz (például jogszerü-jogszerütlen, rentábilis-nem rentábilis stb.) hozzárendelve lehet megalkotni. Ez növeli meg az egész társadalom és a funkcionális részrendszerek rezonanciaképességét, ami azonban azt eredményezi, hogy a modernitás szakít a morálkód dominanciájával (Luhmann 1993b), és ez szükségszerűen együtt jár a morál társadalmat integráló szerepének a háttérbe szorulásával. Annál is inkább, mivel ebben a társadalomszerkezetben a döntő változás csak a részrendszerek és kódjaik keretei mentén következhet be, míg a morális ítéletekre egyre kevésbé rezonál a társadalom. (Miként erre már Talcott Parsons elemzései is rámutattak, ez a folyamat az érték mint kommunikációs médium inflálódásával jár együtt, ami szintén a morális kommunikáció sikerességének esélyét csökkenti a modern társadalomban [vö. Parsons 1968]). Mindebböl pedig az is következik, hogy a morális indíttatású követelésekkel jelentkező zöldmozgalmak nehezen tudnak mit kezdeni a modernitás funkcionális tagolódásának „amorális” megkülönböztetésével; miként az utóbbiak sem tudnak kívánatos válaszokat adni az ökológiai törekvésekre. A jelenségegyüttest a rendszerelmélet felől és Luhmann morálszociológiai vizsgálódásaiból szemlélve arra jutunk tehát, hogy a fenti tényezők miatt a környezeti mozgalmak morális kommunikációjának jelentős korlátai vannak. 
A luhmanni rendszerelmélet sem tért ki azonban a moralitás kérdésének néhány, vizsgálódásunk szempontjából fontos aspektusára. ${ }^{7}$ A továbbiakban azokat a tényezőket értelmezem, amelyek a morális kommunikációban rejlö potenciált emelik ki a modern társadalomban. ${ }^{8}$ Az elemzés célja az, hogy ezen keresztül értelmezhessük a zöldmozgalmak morális kommunikációjában lévő lehetőségeket és azokat a tényezőket, amelyek sikeresebbé tehetik az ökológiai üzenet társadalmi megjelenítését. A morális kommunikáció esélyét az biztosítja, hogy a modern társadalomban nem szünt meg, csak háttérbe szorult a morálra utaló kommunikáció. Ugyan kétségtelenül nem strukturálja alapvetően a részrendszerek kommunikációját, de szerepet játszik a társadalmi intézményekben, a családokban, és a személyek megítélésében. Úgy is fogalmazhatnánk, hogy a morál a modern társadalomban cirkuláló kommunikációs kódként van jelen.

Ez a morális kommunikáció nem annyira erős hatású, hogy a korábbi korszakokhoz hasonlóan képes legyen a morálisan nem helyes kommunikációt megakadályozni, miként arra sem lehet képes, hogy a társadalom egysége, integrációja fölött őrködjön. De szerepet tud játszani abban, hogy a specifikus morálok kialakulásának folyamata felerösödjön. Ennek az a jelentősége, hogy a társadalmi makrostruktúrák amorális megkülönböztetései mellett életre tud hívni olyan morálokat (jelen esetben például a környezetetikákat), amelyek másképpen reflektálnak etikai kérdésekre, és amelyekben értelemszerüen a környezetvédelmi szempontok a korábbinál jóval hangsúlyosabban vannak jelen. Ezek a hatások ugyan nem tudják felülírni a nagy részrendszerek racionalitását, de a morális üzenetekben jelenlévő értékrendjük új impulzusokat tud adni a társadalmi kommunikációnak, és ezzel együtt új irritációkat is képez a részrendszereknek. Ez természetesen csak szükséges, de nem elégséges feltétele annak, hogy az ökológiai kommunikáció hatni tudjon a részrendszerek racionalitására.

A morális kommunikáció lehetőségeit erősíti az is, hogy a modernitás kommunikációja sem lehetne sikeres akkor, ha a morális kommunikáció a saját elismerés-megvetés megkülönböztetésével (a részrendszerek sajátos racionalitásától függetlenül) nem járulna hozzá a kommunikáció bizonytalanságának csökkentéséhez. Erre ugyan a funkcionálisan tagolódó részrendszerek (más terminológiával a modernitás rendszerszerü szerveződései) kevéssé ráutaltak, de a személyek és kisközösségek (más terminológiával az életvilág szférái, vö. Habermas 2011) számára változatlanul lényeges szerepet töltenek be. A morális kommunikáció formálja azt a normaképződést, amely a társadalmilag releváns értékeket újra- és újradefiniálja. Ez kínál lehetőséget arra, hogy a meglévő értékek megszilárduljanak vagy megkérdőjeleződjenek. Másfelől ez tud elindítani egy olyan folyamatot, amelyben az értékek értékének súlya, szerepe megváltozhat a társadalmi kommunikációban. Utóbbi összefüggés arra utal, hogy a modern társadalomban konszenzus van arról, hogy mely értékek fontosak, de annak megítélése nagyon eltérő, hogy az egyes értékek (például szabadság, egyenlőség, testvériség, egészség, empátia stb.) milyen jelentőséggel bírnak.

7 Luhmann saját elméleti pozícióját egyrészt mesterével, Talcott Parsonsszal, másrészt a kritikai társadalomelmélettel folytatott vitája határozta meg. Mivel mindkét irányzat erőteljesen hangsúlyozta a morál és az ebből levezetett értékek szerepét a modern társadalom szerveződésében, a saját útját kereső szociológust ez talán túlságosan is elutasítóvá tette a morál társadalmi szerepét illetően. Feltehetően ezzel a perspektívával magyarázható az is, hogy a nyolcvanas évekbeli zöldmozgalmakkal vitatkozva Luhmann annak a félelmének adott hangot, hogy az inkább konfliktusokat, mint konszenzust generáló morális kommunikáció több problémát okozhat a társadalomnak, mint maguk a környezeti károk (Luhmann 1996b).

8 Luhmann rendszerelméletéből indul ki Pokol Béla is, aki a morál kérdésében szintén Luhmann-nal polemizáló belátásokra jut (Pokol 2005, 2010). 
Ennek a társadalmi folyamatnak több szempontból is jelentősége van az ökológiai kommunikáció érvényesülése szempontjából. A környezetvédelem álláspontját megjelenítő morális kommunikáció egyrészt olyan környezeti értékeket (a biodiverzitás védelme, a jövő generációk iránti felelősség stb.) tud társadalmilag relevánssá tenni, amelyek korábban egyáltalán nem vagy csak periferikusan voltak részei a társadalom értékeinek. Másrészt abban is közrejátszik, hogy a környezeti szempontok mentén történő (zöld)reflexiók immár hangsúlyosan lehetnek részei a társadalom önleírásának. Ez pedig idővel óhatatlanul azt eredményezi, hogy a környezetvédelem olyan értékként jelenik meg, amelynek fontosságát immár a személyek jelentős része, vagy akár többsége is előbbre teszi az értékrangsorban.

A modern társadalom funkcionálisan tagolódó részrendszerei nem zárják ki ennek az átalakulásnak a lehetőségét. Társadalomelméleti fejtegetéseim alapján azonban amellett érvelek, hogy ez a társadalmi változás leginkább a részrendszerek szerveződésén kívül tud elindulni. Itt teremtődhet meg az a „rezonancia”, amely a környezetvédelem ügyét a társadalom számára fontos kérdésként ismeri fel. Az interakciókban és a társadalom hagyományos „multifunkcionális” egységében, a családban lehet jelen az a morális kommunikáció, amely - mint elsődleges szocializációs közeg (vö. Berger és Luckmann 1998) - más értékek közvetítése mellett a környezetvédelem iránti affinitást is kialakíthatja. Ugyan nem vitatható, hogy a modern társadalom szerveződése szempontjából a családnak csak másodlagos szerepe van a társadalom makrostruktúráját meghatározó rendszerszerű szerveződésekhez képest, ${ }^{9}$ de az itt erőteljesebben megjelenő értékváltozás új impulzusokat, irritációkat tud közvetíteni a társadalom részrendszerei számára. Ezek a hatások - más tényezőkkel együtt - képesek módosítani azok müködését, és ennek részeként a környezetvédelem perspektívája is hangsúlyosabban jelenhet meg a társadalmi kommunikációban.

Természetesen a részrendszereken kívül történő változások önmagukban nem elegendők ahhoz, hogy a társadalom affinitását a környezeti kérdésekre átstrukturálják. A modernitás szerveződésében elsődleges szerepü részrendszerek bevonódása nélkül ugyanis egyetlen társadalmi érték sem tud rögzülni és nem képes arra, hogy a társadalom értékrangsorában előkelőbb pozíciót foglaljon el. A részrendszerek fogadókészsége szükséges tehát ahhoz, hogy a környezeti értékek iránti elköteleződés megerősödjön a társadalomban. Az ökológiai kommunikáció esélyét növeli az, hogy a társadalom egyes területei között meglévő strukturális kapcsolódás és a modernitás részterületei közötti nagy dinamika biztosítja az új impulzusok bekerülését.

A legközvetlenebb kapcsolódás lehetőségét a tömegmédia részrendszere kínálja. Ez az egyetlen rendszer a modern társadalom részrendszerei között, amely ugyan - a többi részrendszerhez hasonlóan - amorális kóddal (az informatív-nem informatív megkülönböztetéssel) szelektál a kommunikációkban (Luhmann 2008e), de amely kifejezetten nyitott a morális üzenetekre. Az egyes híreknek, eseményeknek az ad gyakran hírértéket (vö. Angelusz 2003), hogy valamiféle normaszegésről tudósítanak. A moralizálás és az elismerés-megvetés sémája ekképpen az értékekre, és így a környezeti értékekre való reflexió lehetőségét is magával hozza. Nem véletlen tehát, hogy a tömegmédia részterülete közvetíti leghatékonyabban a környezetvédelem üzenetét, és ez képes nemcsak mozgósítani, de elkötelezetté is tenni a környezeti értékek mellett.

9 Ebben a kérdésben a társadalmi jelenségeket sokszor homlokegyenesen másképp látó Habermas és Luhmann között is konszenzus van (vö. Habermas 1993; ill. Luhmann 2002b). 
A tömegmédia racionalitása ugyan lehetőséget kínál a környezeti értékek megjelenítésére, de sajtos szelekciója értelemszerüen nem a környezetvédelem üzenetének sikeres közvetítésére szerveződött. Ebből fakad, hogy működése korlátot is szab a környezeti kérdések tematizálásának és a zöld értékrend elterjesztésének. A tömegmédia üzeneteinek ugyanis mindenekelőtt informatívaknak kell lenniük, és nem egy kérdéskör tárgyszerű és jó tájékozódást biztosító bemutatására törekszenek. Informativitást azonban csak az tud biztosítani, ami eltér a hétköznapok szokványos működésétől, ami atipikus, vagy aminek aktualitását és hírértékét valamely konkrét veszélyérzet, félelem adja. E szelekciós séma mentén jelenik meg a környezetvédelem kérdése is, és ez eredményezi azt, hogy a tömegmédia komplexebb, vagy akárcsak hitelesebb kép megrajzolására sem alkalmas. A környezeti értékek melletti elköteleződést nehezíti a félelemre apelláló, a megszólítottakat gyorsan bekövetkező világvégével riogató médiahírek nem szándékolt következménye. Ezek a közvetlen veszélyről szóló, szenzációhajhász tudósítások, ha hinni lehet a kognitívdisszonancia-elméleteknek (Festinger 2000), a befogadóknál sokkal inkább az üzenet kétségbevonását, mint a vágyott és a zöldmozgalmak által megcélzott tudati változást tudják elérni.

A morális kommunikáció által közvetített környezeti értékek jelenlétét a részrendszerekben azonban nemcsak a tömegmédia tudja megjeleníteni. Mint már utaltam erre, e tekintetben az oktatási rendszernek vannak szabadabb vegyértékei a kapcsolódáshoz. Annál is inkább, mert ennek a társadalmi részrendszernek úgy kell közvetítenie a társadalmilag releváns tudásokat, hogy sikeresen tudják megszólítani az oktatásba bejövő generációkat. A részrendszerek szféráján kívül (az interakciókon, a családon) és a tömegmédián keresztül közvetített környezeti értékek az új generációk esetében már jóval inkább kondicionáltak, és szinte elvárásként fogalmazódnak meg a közoktatással szemben is. E tényezők pedig azt eredményezik, hogy az oktatási rendszer is nagyobb hatékonysággal közvetítheti a környezeti szempontokat.

A kisebb strukturális változások megerősítést nyernek a nyilvánosság diskurzusában is, és nagyban elősegítik, hogy a morális kommunikáció által indikált változás más társadalmi területekre is kiterjedjen. Ugyan kevéssé érzem védhetőnek azt, hogy a habermasi elképzeléseknek (Habermas 1993, 2011) megfelelően a nyilvánosság egyaránt képes lenne a mindenkori közhatalom ellenőrzésére, a kommunikatív kompetencia gyakorlására, és úgy általában a társadalmi konszenzus deliberatív megvalósítására (vö. Peters 2007; Bognár 2015), de kétségtelenül hatékonyan tematizálja mindazokat a kérdéseket, amelyek a társadalmi kommunikációban lényegesnek mutatkoznak. A környezeti értékek a fentiekben leírt csatornákon, illetve a további strukturális kapcsolódásoknak köszönhetően egyre inkább jelen tudnak lenni azok között az értékek között, amelyek immár olyan súllyal rendelkeznek, hogy képesek erőteljesebben irritálni a részrendszerek müködését.

\section{A kulturális átalakulások hatása a környezetvédelem társadalmi percepciójára}

A környezeti szempontok társadalmi érvényesülésének esélyeit és korlátait az ökológiai kommunikáció és a társadalom komplex viszonyának ábrázolásával igyekszem bemutatni. Amellett érvelek, hogy az új környezettudatosság radikális programja nem képes döntő változást hozni a környezetvédelem területén. Többek között azért sem, mert a protesztmozgalmak 
értelmezési pozíciója már önmagában is paradoxonnal terhelt: a környezetetikák ugyanis a természetes egyensúly fenntartását, a be nem avatkozás politikáját (tehát egy autonóm rendszer önállóságát) képviselik, miközben ezzel párhuzamosan a társadalom radikális átalakulását célozzák meg. Eddigi elemzésem arra mutatott rá, hogy ez a program csak kevéssé talál csatlakozási pontokat a modern társadalom összetett struktúrájában központi szerepet betöltő részrendszerekhez, mert a társadalom e területeinek szerkezete a saját rekurzív tevékenységük által meghatározott, és működésük csak az olyan külső impulzusokkal módosítható, amelyekhez az egyes rendszerek megtalálják a kapcsolódásokat.

A protesztmozgalmak saját céljaik mentén értékelt sikertelensége ezt a társadalomelméleti belátást erősíti meg. Másfelől a mélyebb társadalmi gyökerekkel rendelkező morális kommunikációban megjelenő környezeti szempontok - ha kis hatékonysággal is, de - hosszabb távon képesek az egyes részrendszereket formálni. A modern társadalom komplex müködése a tartósságot biztosító rekurzív struktúrák mellett rendelkezik annyi dinamikával, hogy az újabb kihívásokra válaszolni tudjon. Az ökológiai kommunikációnak az utóbbi években megnövekedett jelenléte a továbbiakban taglalt egyéb tényezőkkel együtt szerepet tud játszani abban, hogy a társadalmi kommunikáció egyre hangsúlyosabb kérdésként tematizálja a környezeti kérdéseket; még ha azok messze nem a környezetvédők által kívánt mértékben jelennek is meg az egyes részrendszerek szelekciójában. Ez ugyan nem módosítja alapvetően az egyes részterületek müködését, de a környezeti kérdések hangsúlyosabban jelen vannak a mérlegelendő szempontok között, és a környezeti kockázatok hosszabb távú következményeit is inkább mérlegelik a döntési helyzetekben (Luhmann 1996a).

Úgy látom azonban, a változásnak sokkal több eredője van annál, hogy a környezeti kérdések hangsúlyosabb jelenlétét egyszerüen a protesztmozgalmak által közvetített morális kommunikációnak tulajdonítsuk. Ennek folyamatos hatása ugyan kétségtelenül kondicionálta a környezeti kérdésekre való affinitást, de önmagában nem lett volna elég ahhoz, hogy a környezeti kérdéseket a társadalom fontosabbnak ítélt problémái közé soroljuk. Ehhez a modern társadalomban súlyát vesztő morális kommunikáció nem tud elég erős irritációkat képezni az amorális kóddal múködő részrendszerek számára. Meglátásom szerint a nyugat-európai és észak-amerikai közéleti diskurzusban a környezetvédelem megnövekedett fontossága öszszefügg az utóbbi évtizedekben lejátszódó kulturális változásokkal is. Ennek több dimenziója is a környezeti kérdések hangsúlyosabb jelenlétét eredményezi. Miként erre az utóbbi évtizedek értékszociológiai kutatásai rámutattak, az egyik lényeges változás a posztmateriális értékek előtérbe kerülése. Az Inglehart által csak „csendes forradalomnak” (Inglehart 1977) nevezett átalakulás során a gazdasági érvényesüléshez köthető hagyományos értékek helyett az önmegvalósítást, a politikai értékek és politikai cselekvések felvállalását megfogalmazó posztmateriális értékek váltak lényeges tájékozódási ponttá (Inglehart 1997; Inglehart és Baker 2000; Inglehart és Welzel 2005). Ez a megváltozott értékorientáció pedig nyilvánvalóan megnövelte a környezeti kérdések szerepét. Annál is inkább, mivel a kutatások egyértelmúen erős korrelációt mutatnak a posztmateriális értékek melletti elköteleződés és a környezetvédelem fontossága melletti állásfoglalás között (Inglehart, Basanez és Moreno 1998). A környezeti értékek megnövekedett szerepe mögött tehát nem egyszerüen a protesztmozgalmak ökológiai kommunikációjának hatása, hanem egy ennél mélyrehatóbb strukturális változás húzódik meg. Ennek következménye pedig többek között az lett, hogy - különösen a fiatalabb korosztályokban - megerősödött a környezetvédelem melletti elköteleződés. 
A posztmateriális értékek elterjedése az utóbbi évtizedek egyik leglátványosabb kulturális átalakulása volt a nyugati civilizációban. Ronald Inglehart átfogó empirikus elemzése (Inglehart 2018) szerint napjainkban egy újabb lényeges kulturális átalakulás játszódik le. Az utóbbi évek gazdasági, politikai válságai, a menekülthullám, a hagyományos etnikai, kulturális közösségek egyre nagyobb mértékü veszélyeztetettsége alapvetően változtatja meg az emberek viselkedését és értékeit. Ennek legfőbb oka az, hogy az új társadalmi körülmények között az évtizedeken keresztül biztosnak tűnő létfeltételek kérdésessé válnak. A stabil, kiszámítható életpálya, a munkahely biztonságának megszünése, a radikálisan növekvő társadalmi és jövedelmi különbségek csak szimptómái ennek a változássornak. Mostani vizsgálódásom szempontjából annak az értékváltozásnak van elsősorban jelentősége, amelynek során az Inglehart által kiemelteken (az etnocentrizmuson, a kívülről jövők elutasításán, az erős vezetők elfogadásán stb.) túl nagyobb figyelmet kapnak azok a tényezők, amelyek az életet közvetlenül veszélyeztetik egy olyan „kulturális evolúció” (Inglehart 2018) korszakában, amikor a létbizonytalanság alapvető élménnyé válik. A környezetszennyezés pedig ebben a megváltozott percepciós sémában nyilvánvalóan ilyen tényezőként jelenik meg. Ebben a társadalmi kontextusban a negatív környezeti hatások a bizonytalan, de átvészelhetö jelen mellett a jövőt is bizonytalanná formálják, jelentős mértékben hozzájárulva az egyének aggodalmainak erősödéséhez, különösen egy olyan időszakban, amikor a környezeti problémák egyre inkább mindenki számára érzékelhetővé válnak.

Napjaink sajátszerüsége pedig éppen az, hogy a környezetkárosítás immár nem csupán egy távoli jövő problémájaként jelenik meg, hanem olyan kérdésként, amely a jelenbeli történésekre is kihat. A környezeti veszélyek több évtizedes médiabeli jelenléte után a nyugati ember most először találkozik a környezetszennyezés egyre aggasztóbb, és immár őt személy szerint is érintő hatásaival. Az egyre szélsőségesebb időjárás okozta áradások, hurrikánok és az ezek következményeiként átélt katasztrófahelyzetek ugyan nem mindennaposak, de a jelenben potenciálisan átélhető „élmények” alapját képezik. A globális felmelegedés okozta szárazság és a sokszor elviselhetetlen meleg pedig mindenki által érzékelt és megszenvedett jelenséggé váltak. A környezeti katasztrófa immár nem egy utópisztikus hollywoodi film megborzongató, ám mégis inkább csak kellemes kikapcsolódást jelentő képsoraiban jelenik meg, hanem akár a közeljövőben megtapasztalható személyes tragédiaként is az emberek gondolkodásában. Ezeket a személyes tapasztalatokat erősíti fel a kulturális változás folyamata. A külső kockázatok által befolyásolt élményvilág és a létbizonytalanság a környezeti veszedelmeket is valósabbá és fontosabbá avatja.

A környezetvédelem ügye tehát több tényező miatt kapott nagyobb szerepet a társadalmi kommunikációban. A morális kommunikáció jelentette hatás, a modern társadalom azon kulturális átalakulása, amely előtérbe helyezte a posztmateriális értékeket, a napjainkban lejátszódó kulturális evolúció, amely a létbizonytalanság miatt nagyobb hangsúlyt kölcsönöz a környezetszennyezés kérdésének, és az immár személyesen megtapasztalt környezeti változások egyaránt szerepet játszanak abban, hogy a nyugati civilizációban a környezeti kérdések a társadalom fontos kérdéseként tematizálódnak. Ezek képezik tehát a legfontosabb „rendszerirritációkat”. Ennek csak egyik, de felettébb lényeges dimenziója, hogy a környezetszennyezés sokak által megtapasztalt következményei és egyre durvább jövőbeli hatásai is formálják a személyek percepciós sémáit. Mindezen tényezők következményeképpen a környezeti problémák kikerülnek a jelen lévő, de aktualitással nem rendelkező kérdések közül, 
és egyre inkább a jelent érintő, ezért a jelenben orvosolandó kérdések közé sorolódnak. Ez a percepciós változás pedig olyan átalakulásokat tud eredményezni, amelyek a részrendszerek szelekcióját is sikeresebben tudja irritálni, és nagyobb esélyt kínál a környezeti kérdések eröteljesebb szerepére a társadalmi kommunikációban.

Ebben a változássorban fontos szerepe van a közvéleménynek. Itt ugyan aligha alakulhat ki konszenzus a társadalmilag kívánatos cselekvésről (vö. Luhmann 1969; Brunczel 2010: 171-176; Bognár 2015), de a nyilvánosság mégiscsak olyan fórumot jelent, ahol a társadalomban cirkuláló egyes témák, kérdések megjelenhetnek. Társadalmi szerepe ahhoz köthetö, hogy a társadalomban kevés megkötés létezik a politikai kommunikáció tartalmaira vonatkozóan, a nyilvánosság pedig képes arra, hogy a politika hatékonyabb müködése érdekében szelektálja a témákat és a hozzájuk kapcsolódó véleményeket. Azzal, hogy szűkíti, de nem determinálja a kommunikációt, megteremti a politika számára a másodlagos szelekciót.

A morális kommunikáció önmagában elégtelen súlyú, de a többi, a fentiekben elemzett tényező megerősítő hatásának eredményeképpen a környezeti értékek súlya megnövekedett a társadalmi kommunikációban, ami átalakítja a nyilvánosságban tematizálódó kérdések szerepét is. A nyilvános diskurzusban témaként már hosszabb ide jelen lévő környezeti kérdések a megemlített, de inkább periferikus problémák közül a fontosabb témák közé kerülnek. Ez a pozícióváltozás pedig óhatatlanul azt eredményezi, hogy a politikai részrendszer számára előszelektáló nyilvánosságban a környezeti kérdések a politikai racionalitást is egyre inkább képesek befolyásolni. Ez mutatkozik meg abban, hogy az utóbbi években a környezetvédelem ügye a politika számára a fontosabb kérdések egyikévé vált. A környezetvédelem kezelése természetesen nem írja felül a politikai rekurzív szerkezetét, de különösen a jövőre vonatkozó víziókról (is) döntő választásokon a leglényegesebb témák között bukkan fel. Ez kínál esélyt arra, hogy a környezeti értékek tartósan és a hosszabb távú döntésekben is szerepet játsszanak. A részrendszerek strukturális kapcsolódása miatt ez a hangsúlyeltolódás természetesen hatást gyakorol a többi fontos részterületre (gazdaság, jog, oktatás stb.) is.

A több elemből álló változássor eredményeképpen tehát a társadalmi részrendszereken kívül lassan olyan perspektívák jelennek meg, amelyek fontos impulzusokat jelentenek az egyes részrendszerek racionalitása számára - ezáltal ugyan nem jönnek létre a protesztmozgalmak által megcélzott radikális változások, de fokozatos adaptációk igen. Az adaptációk és a rekurzív kommunikációs szerkezetek módosulása kölcsönösen mennek végbe. Az egyes részrendszerek egyrészt olyan átalakulásokon mennek keresztül, melyek következtében ugyan nem íródik felül a racionalitásuk, de amelyek révén a környezetetikai szempontok mégis megjelen(het)nek a részrendszerek sajátos szelekciójában. Ez mutatkozik meg a gazdaság müködésében, amely a rentabilitást csak bizonyos közép- és hosszútávú környezeti hatások figyelembevételével gyakorolhatja. Vagy ezt láthatjuk a jog részterületén, ahol a jogalkotás csak a kockázatok közép- és hosszútávú következményeinek határozottabb beépítésével történhet meg. A változás kölcsönössége másrészt abban is megmutatkozik, hogy a környezeti kérdések folyamatos jelenléte a részrendszerek környezetében és a nyilvánosságban újabb környezetetikai szempontokat vet fel, ami kiterjeszti és hatékonyabbá teszi az ökológiai kommunikációt. Mindez a környezeti tényezők nagyobb jelenlétét eredményezi a társadalmi kommunikációban. Értelmezésem szerint a világtársadalom (vö. Luhmann 1991b; Stichweh 2000) nyugati régióit most éppen ez a folyamat jellemzi. 


\section{A környezetvédelem melletti elköteleződés generációs és miliőstrukturális összefüggései}

A sokdimenziós változássorban többek között a percepciós sémák és értékek jelentőségét emeltem ki, e sémák és értékek azonban a társadalom különböző csoportjaiban eltérő súllyal jelennek meg. A környezetvédelem ügye elsősorban azokat a korosztályokat tudja megszólítani, amelyek számára a családi környezet, az oktatási rendszer nagyobb mértékben közvetített ilyen tartalmakat. Másfelöl azok esetében valószínübb, hogy reflektálnak a környezeti értékekre, és hogy elköteleződnek mellettük, akiknek a világ megtapasztalása során nem kellett egy másfajta korszellem jegyében ezen értékekkel ellentétes, vagy őket alapvetően negligáló megközelítéseket elsajátítaniuk (vö. Mannheim 2000; Ortega 2003). Mindkét vonatkozásban a fiatalabb generációk azok, amelyeket a körülményeik arra kondicionáltak, hogy az értékrendjük fontos részeként tematizálják a környezeti kérdéseket - szemben azokkal a generációkkal, amelyek esetében sem a családi közegben, sem az oktatási rendszerben, sem a nemzedéki tapasztalatban nem jelentek meg a környezeti problémák meghatározó kérdésekként.

A fiatalabb korosztályok fogékonyságát feltehetően az is növeli, hogy e generációk nem azt élik meg, mint az idősebb nemzedékek, melyeket évtizedekig „riogattak” a környezeti veszélyekkel, de nem tettek szert személyes tapasztalatra ezzel a problémával kapcsolatban, hanem a fiatalabbak azt érzékelik, hogy a környezeti veszélyekről szóló közéleti polémiákkal egy időben jelennek meg a környezetkárosítások nyilvánvaló következményei is. A generációs élmények eltérései különböző percepciós sémákat, valóságkonstrukciókat eredményeznek. Ehhez járul hozzá az is, hogy a fiatalok eleve a jövő felé orientálódnak, így a közeli jövőben megváltozó természeti környezet is fontosabb a gondolkodásukban, és mivel életkoruknál fogva nyitottabbak a posztmateriális értékekre. Ráadásul az, hogy a jövő felé orientálódnak, óhatatlanul együtt jár valamiféle bizonytalansággal, szorongással, mert nem lehet tudni, hogy miként alakul a sorsuk. Emiatt a fiatalok nagyobb érdeklődést mutatnak az eleve szorongást keltő környezeti kérdések iránt. Ezek a szociológiailag megragadható összetevők mutatkoznak meg napjaink zöldmozgalmaiban: a környezeti kérdések sokkal inkább a fiatalabb korosztályokat szólítják meg, a mozgalom szószólói (például Greta Thunberg) pedig nem ritkán a tízes éveiben járók közül kerülnek ki.

A környezetvédelem fontosságának megítélése a nemzedéki tapasztalatokon túl attól is függ, hogy a társadalmi valóságot milyen eltérő sémák alapján tapasztalják meg, ezek pedig a generációkon belül is különböznek. A külvilágot megérteni akaró személy perspektíváját alapvetően az határozza meg, hogy milyen tartalmú szempontrendszerrel közelít a körülötte lévő világhoz. A miliőkutatások (például Schulze 1992; Berger 2008) az információkat hasonlóan szelektáló és interpretáló értelmezési, tudás- és élménycsoportokat, ún. miliőket különítenek el, melyek számára a társadalmi valóság lényegesen különböző módon jelenik meg, és a percepciós sémájukban egészen más súlya van a környezeti kérdéseknek. A fiatalabb generációk miliői ugyan osztoznak abban, hogy egyaránt az én megtapasztalására helyezik a hangsúlyt, de ennek sémája eltérő mintázatot mutat (Schulze 1992; Éber 2007, 2008).

A fiatalabb korosztályok kevésbé képzett tagjai esetében az én és a világ viszonyában az előbbi a fö viszonyítási pont, de ebből a viszonyból hiányzik a dinamika, ugyanis e miliő élménysémájában az én kielégítése áll a középpontban. E miliő tagjai ezért olyan erős ingereket, stimulációkat keresnek (például autóversenyzés, akciófilm, pornó stb.), amelyek által 
erős és intenzív élményekre szeretnének szert tenni, mintsem pontos információkra és elmélyült elemzésekre. Nem meglepő módon nem ez a - tegyük hozzá, többségi - csoportosulás lesz annak a zöldmozgalomnak az elkötelezettje, amely a társadalmi kérdések áttekintésén és a megújulási lehetőségek felmutatásán keresztül alapvető változásokat követel. A környezetvédelem ügye iránt sokkal inkább azok a képzettebb fiatalok mutatnak affinitást, akik élménysémájukban ugyan szintén az énjükre, mint „belső lényegükre” koncentrálnak, de legfőbb feladatuknak ennek dinamikus kibontakoztatását tekintik. Perspektívájuk alapján erőteljesebben reflektálnak az én társadalmi környezetére is, mint e kibontakozás feltételrendszerére. Ugyanakkor élményparadigmájukban egyaránt törekednek az intenzív élményekre és a kontemplációra - e kettősség a bohém életvitelében testesül meg. Mivel a müvész mítoszához hozzátartozik a sikeresség is, az e miliőjöz tartozók szeretnének befutott, elismert személyek lenni, akiknek a teljesítménye fölött a társadalom egésze adózik.

A fiatalabb és képzettebb miliő tagjait ezek a percepciós sémák teszik a környezeti mozgalmak élharcosaivá és a környezeti kérdések iránt elkötelezett csoport részévé. A kontemplációra vonatkozó nagyobb igény teremti meg a közéleti kérdések iránti érdeklődést. A csoport fö perspektívájának a középpontjában szintén az én áll, így számukra a sokféle környezeti kérdés közül azok válnak igazán fontossá, amelyek kapcsán az én közvetlen veszélyeztetettsége megtapasztalható. A környezet ügye melletti nemegyszer harcos kiállás pedig olyan erős ingereket ígér, amelyek túlmutatnak a pillanatnyi kielégülést szolgáló szórakozáson (például a házibulikon), és egyúttal az én sikeres társadalmi megjelenítésének a lehetőségét is biztosítják. A környezet ügye melletti elköteleződés ugyanis egyaránt garantálja az azonos miliőkben lévők elismerését és azt a szélesebb (média)figyelmet is, amely a befutás, a fontosság élményét is átélhetővé teszi.

A miliőstrukturális jegyek több szempontból befolyásolják a környezeti mozgalmak karakterét és mozgásterét. A környezeti mozgalomban elkötelezett miliő a fiatalabb korosztályok kisebbségi csoportját jelenti, ami azt is jelzi, hogy ugyan a környezeti kérdések iránt növekvő affinitás van a társadalomban, de a társadalom nagyobb csoportjai esetében még nyugaton sem történt meg az áttörés. A környezeti mozgalmak esélyét növeli azonban, hogy az a kisebb létszámú miliő, amelyből az ökológiailag elkötelezettek többsége jön, több olyan jeggyel rendelkezik, amelyek a nagyságánál nagyobb súlyt biztosítanak e miliőnek ahhoz, hogy a környezetvédelem ügyét hatékonyan képviselje. A nyilvánosság közéleti diskurzusában aránytalanságok vannak, amelyek a különböző miliőknek (attól függően, hogy az egyes miliők tagjai milyen készségekkel rendelkeznek, vö. Bognár 2015) eltérő lehetőségeket biztosítanak a közéleti vitákban való részvételre, ami kedvező feltételeket kínál a környezeti problémák társadalmi megjelenítésére. A környezettudatos miliő ugyanis képzettsége, a közéleti kérdések iránti nagyobb fogékonysága, jobb érdekérvényesítő képessége, a racionális vitákban való nagyobb jártassága miatt jobban látható és nagyobb hatása van a nyilvánosság diskurzusaira, ami által képes „hangos kisebbségként” olyan benyomást kelteni a nyilvánosságban, mintha sokak, sőt a többség igényeit fejezné ki, amikor nagyobb súlyt követel a politikában és a társadalom egyéb részrendszereiben a környezeti kérdéseknek.

A környezetvédelem ügye iránt elkötelezett, de mégis kisebbséget jelentő csoportok domináns jelenléte a tömegmédia csatornáiban olyan tényező, amely nem csupán a társadalom egy részterülete szempontjából érdekes: hatása az egész társadalomra ki tud terjedni. Ennek oka az, hogy a modern társadalomban a társadalomról szóló diskurzust egyre inkább a tömegmédia határozza meg (Luhmann 2008e). A világról szóló tudásunk legfőbb forrása 
a tömegmédia, amely ezáltal elsődleges szereppel rendelkezik a társadalom önleírásában is. A társadalomról főként azt tudjuk meg, amiről a tömegmédia tudósít. Ha pedig a társadalom megtapasztalásában főszerepet kapó médiában a környezetvédelem ügye kiemelt kérdésként jelenik meg, akkor idővel ez a hangsúlyos jelenlét jó eséllyel azoknak a csoportoknak a percepcióját is befolyásolni fogja, amelyek számára az ökológiai kérdések eredetileg nem voltak lényegesek.

Mindezen összefüggések mentén úgy látom, hogy a környezetvédelem ügye és a környezeti értékek most válnak a nyugati világban olyan tényezőkké, amelyek már határozottabban tudják formálni a társadalmi kommunikáció tartalmait. E kijelentésből azonban magától értetődően nem következik az, hogy a környezeti szempontok nagyobb szerepe szükségszerüen lehetőséget kínálna a környezetkárosítástól veszélyeztetett társadalom fennmaradására. Itt nem csak arról van szó (miként erre már utaltam), hogy a modern társadalom nem rendelkezik ez irányú teleológiával. A jövő prognosztizálása azért is lehetetlen, mert a modern társadalom komplex rendszerében túl sok tényező egymásra hatása formálja a folyamatokat.

Az, hogy sikeres válaszok születnek-e a környezeti problémákra, azonban mindezeken túl azon is múlik, hogy a világtársadalom müködését a közeljövőben melyik régió fogja dominálni. Megőrzi-e a vezető szerepét az a Nyugat, ahol hosszú idő alatt kiformálódott a környezeti kérdésekre irányuló reflexió képessége, és ahol - lassú strukturális változások után a környezeti értékek fontos tényezőkké váltak, vagy az a Kelet fogja a társadalmi folyamatokat leginkább generálni, ahol az eredeti tőkefelhalmozás mostani időszakában a környezeti szempontok rendszerszinten többnyire értelmezhetetlen kérdések. A kérdés ugyan nem dőlt el véglegesen, de a mostani tendenciák az utóbbit valószínüsítik.

\section{A környezetvédelem esélyei a félperiférián - a magyar helyzet sajátosságai}

Külön elemzést kívánna meg az, hogy a világtársadalom keleti régiójában milyen helyi értékkel bír a környezetvédelem. A továbbiakban azonban csak a nyugati régióval érintkező Magyarország sajátosságaira reflektálok. A hazai viszonyok sok tekintetben eltérnek az eddig értelmezettektől. Magyarország abba a kelet-közép-európai régióba tartozik, amelynek a nyugatitól eltérő társadalomtörténete más szerkezetű berendezkedést alakított ki (Hajnal 1942a, 1988, 1993; Szücs 1983; Kemény 2010). A funkcionalista elemzés perspektívájából a legfontosabb eltérés az, hogy e régióban csak korlátosan tudtak kialakulni a részrendszerek önálló szerkezetei, amelyek alapján e részrendszerek saját autonómiájuknak megfelelően szelektálják a kommunikációkat. A régióban ugyan elindult az a folyamat, amely létrehozza a rentabilitás alapján szervező gazdaságot, a jogszerűség alapján tájékozódó jogrendet stb., de a nyugatinál jóval kisebb súllyal és társadalmi hatókörrel. Az egyes részterületek önálló racionalitásának korlátozottabb a hatóköre, mivel nem terjed ki mindazon tevékenységekre, amelyek a Nyugat országaiban e részrendszerekhez tartoznak. Abban is megmutatkozik ez, hogy például az állami beruházások esetében a gazdaság racionalitását felülíró szempontok határozzák meg a döntéseket (Mellár 2017; Bod Péter 2018, 2019a, 2019b), vagy hogy a tömegmédia közpénzen finanszírozott intézményeiben nem az informativitás határozza meg a kommunikáció tartalmát (Pokol 1995; Bajomi-Lázár 2013; Bajomi-Lázár és Horváth 2013).

A térségben ehelyett a (sokszor külső hatalmi tényezők által) központilag megszervezett államhatalom megőrizte azt a döntési hatáskörét, amely nem engedte a részrendszerek auto- 
nómiáját szélesebb hatókörrel kibontakozni, ami egyebek mellett a nyugatinál autoriterebb berendezkedésü rendi struktúrákból következik, és abból, hogy itt a társadalom a Nyugathoz mérten sokkal inkább felülröl szervezett (Gerschenkron 1984) és kevesebb teret enged az autonóm törekvéseknek. (A részrendszerek kialakulása is egyfajta, ebben a régióban csak kisebb mértékben érvényesülő társadalmi autonómia következménye.) Mindennek pedig az lett az eredménye, hogy gazdasági kérdésekben sokszor a rentabilitás helyett éppúgy a központi hatalom racionalitása érvényesül, mint ahogy a jog területén is, ahol a hatalom képes a jogszerüség elvét felülírva döntéseket kieszközölni. (Nyilván a felsorolás folytatható lenne más részrendszerekkel, az oktatással, az egészségüggyel, a tudománnyal, sporttal stb. is.) Mindez nem csupán felülről szervezett társadalmi viszonyokat eredményezett, vagy más terminológiával élve a „szabadság kis köreinek” (Bibó 2016) kevés mozgásteret engedélyező hatalmat, hanem olyan berendezkedést is, ahol a politika uralja a társadalmi kommunikációt, és ahol a politika képes jelentősen befolyásolni az egyéb részterületek kompetenciájába eső.

Az életvilág szféráját éppúgy ez a felülről szervezett hierarchiának nagyobb szerepet adó struktúra határozza meg, mint a külső irritációkra adott válaszokat. A politika sok tekintetben megmutatkozó omnipotenciája miatt a központi hatalom jelentősebb mértékben tudja befolyásolni a családokat és az alulról jövő szerveződéseket. A családi kommunikáció sokkal kevésbé tudja függetleníteni magát a központból jövő üzenetektől, így kevesebb esély van arra, hogy a családi szférában a központ (vagy a társadalom részterületei) által preferált racionalitással szemben új nézőpontok jelenjenek meg. A nyugatinál hierarchikusabban szerveződő társadalmi és intézményi kommunikáció hatása (vö. Gajduschek 2017) megmutatkozik a civil társadalom területén is, amely a nyugati régióhoz viszonyítva sokkal kisebb súllyal rendelkezik a társadalmi kommunikációban. A politika által megjelenített központi hatalom határozza meg elsősorban, hogy milyen válaszok születnek az államot érő külső hatásokra, impulzusokra: a politika kezében lévő források döntően befolyásolják az oktatás, a gazdaság, a tömegmédia müködését, és ezzel az erőfölénnyel ez a részrendszer sikeresebben jeleníti meg a véleményét a társadalom egyéb ágenseihez képest. Mindez pedig olyan kommunikációs szerkezetet alakít ki, amelyet nagyobb rugalmatlanság, alacsonyabb dinamika, és ebből következően rosszabb adaptációs képességek jellemeznek, s amely müködéséből fakadóan kevés lehetőséget ad az új nézőpontok megjelenésének.

Ebben a struktúrában értelemszerüen kisebb mozgástérrel és hatókörrel rendelkeznek a zöldmozgalmak is. Következik ez a fentiekben összefoglalt strukturális viszonyokból: az alulról szerveződő mozgalmak fejletlenebbek (vö. Scheiring 2008) és - különösen a közéleti kérdéssekkel foglalkozó civil szervezetek esetében - inkább csak a nagyobb polgári lakossággal rendelkező nagyvárosokhoz kötődnek. E szerkezeti sajátosság azt eredményezi, hogy a civil szervezetek perspektívája sokkal kevésbé hatja át a társadalom egészét (vö. Bartus 2017), ami miatt vagy csak marginális szereppel rendelkeznek, vagy erőteljesen függenek a nemzetközi szervezetek támogatásától. Előbbi esetben társadalmi hatásuk partikuláris marad, utóbbi esetben felülről, kívülröl finanszírozott civilekké válnak, mely paradox helyzet óhatatlanul olyan politikai játszmák részévé teszi a civileket, amelyekben a civilek nem a követeléseik, hanem a pártpolitikai dimenziók mentén definiálódnak. Nyilvánvalóan egyik pozíció sem azt a lehetőséget erősíti, hogy a civil mozgalmak, jelen esetben a zöldmozgalmak össztársadalmi értékek hatékony képviselői legyenek.

A környezeti értékek sikeres megjelenítését korlátozza az emberek percepciós sémája is. Az évszázadok során társadalomtörténetileg a mindenkori hatalom nézőpontjának elfogadására 
kondicionált társadalmi cselekvők sokkal inkább adnak hitelt azoknak az információknak, amelyeket a hatalmi struktúra csatornái (tömegmédia, oktatás, politika) megerősítenek; és jóval szkeptikusabbak azokkal az alternatív olvasatokkal szemben, amelyek a hatalmi nézőponttól függetlenül, vagy éppen ezzel szemben állóan értelmezik a társadalmi valóságot. Ennek a beállítódásnak a jegyei köszönnek vissza az értékszociológiai kutatásokban (Keller 2010; Tóth 2010) is. A magyarok a nyugati régió lakosainál sokkal kevésbé elkötelezettek a demokratikus értékek mellett, és a hatalomhoz füződő viszonyukat egyfajta paternalista szemlélet jellemzi: azt a hatalmat tekintik kívánatosnak, amely - akár a demokratikus jogok csorbításával is - megszervezi a közrendet és gondoskodik az állampolgár békéjéről és jólétéről.

A környezeti értékek sikeres megjelenítése tehát a nyugati régiónál sokkal inkább ráutalt a hatalmi tényezőkre. Az alulról jövő kezdeményezések túl gyengék ezen értékek társadalmi érvényesítéshez, melyek csak akkor tudnak fontosabb részeivé válni a társadalmi kommunikációnak, ha a felülről szervezett hierarchia is elköteleződik mellette. ${ }^{10} \mathrm{~A}$ környezetvédelem ügyét azonban nagyban nehezíti, hogy ez a hatalom a legkevésbé sem arra kondicionált, hogy a környezeti kérdéseket fontos problémaként tárgyalja, ami a térség társadalomtörténete által meghatározott szerkezetével is magyarázható, ugyanis a régió rendi fejlődése súlyos megszakítottságokkal terhelt (Benda 1991, 1997). Itt sokkal kevésbé volt jellemző az a generációról generációra építkező társadalomfejlődés (a Hajnal István-i szokásszerűséggel jellemezhető társadalomfejlődés [Hajnal 1989, 1998]), ahol az egyes társadalmi területeken „hosszú emlékezettel rendelkező" rekurzív struktúrák alakulhattak volna ki. Egyáltalán nem, vagy kevésbé tudtak létrejönni olyan társadalmi viszonyok, amelyek lassú, de stabil építkezésükkel olyan komplex szerkezeteket hoztak volna létre, amelyek a régmúlt tapasztalatait (és értékeit) is magukba foglalták volna. Ehelyett „,a pillanat érdekhullámzásai” (Hajnal 1942b: 37) által meghatározott, (sokszor katona)politikai döntések formálták a társadalmi berendezkedést, mely döntések perspektívájában mindig a jelen aktuális problémái álltak a középpontban. A strukturálisan meghatározott rövid távú emlékezet a jelenre koncentrál és a jelenbeli hatalmi viszonyok fenntartására irányul, amiből adódóan kevéssé tud olyan összefüggéseket mérlegelni, amelyeknek közép- vagy hosszú távú vonatkozásai az elsődlegesek.

A környezeti értékek társadalmi sikeressége azért erősen kérdéses ebben a struktúrában, mert ehhez olyan nézőpontra volna szükség, amely határozottan a jövőre, tehát nem a jelenre, és legfóképpen nem a jelen politikai hatalmi dimenziójára fókuszál. A perspektíva ezen eltérése mutatkozik meg az értékekhez füződő viszonyban is. A környezeti értékek képviselői a természeti környezet fenntartását tartják fontosnak és azt a beállítódást, amely az állandó növekedés helyett a természeti környezet fenntarthatóságát tüzi ki célul (Lányi 1999; Antal 2015). Ez az értéktételezés a materiális értékek helyett a posztmateriális értékeket veszi alapul, és a fenntarthatóság képviseletében éppen a materiális javakkal szemben foglal állást. Egészen más nézőponttal jellemezhető azonban a másik oldal. A jelenre fókuszáló, rövid távú emlékezettel rendelkezö közhatalom olyan rekurzív struktúrával rendelkezik, amelyben a jövőre fókuszáltság nem tartozik a szerkezetet formáló legfőbb tényezők közé. Számára a jelen sikeres menedzselése és a felülről szervezett hierarchia által kondicionált választópolgár sikeres megszólítása a feladat. Ez a perspektíva pedig óhatatlanul azokat a materiális értékeket állítja a középpontba, amelyekkel a politikai hatalom fenntartása könnyebben megvalósítható.

10 Ezek a strukturális jegyek szabnak szük teret azoknak az előremutató törekvéseknek, amelyek a társadalom kis közösségeiben, alulról szervezett módon (lásd erről Lányi 2010b; Lányi és Farkas 2010; Takács-Sánta 2009, 2017) próbálják megjeleníteni és képviselni a környezeti értékeket. 
A közhatalom stratégiájának sikerességét mutatja a választások évszázadok óta (vö. Kemény 1843-1844; Herczeg 2005) változatlan koreográfiája, amely az államkassza felelőtlen túlköltekezésével (a gazdasági válságtól vagy prosperitástól függetlenül mindig deficittel tervezett költségvetéssel), a polgárok anyagi javakkal való megszólításával (a nyugdíj, a közalkalmazotti és a minimálbér emelésével, a választások előtti közüzemi kedvezményekkel, s ha kell, szavazatvásárlással stb.) igyekszik kommunikálni hatalma hatékonyságát. E stratégia sikerességének társadalmi feltételét képezi, hogy a megcélzott társadalom is osztozik a hatalom értékeiben. A társadalom túlnyomó többsége elutasítja a posztmateriális javakat, és erősen a materiális javakra fixál (Keller 2010; Tóth 2010) ${ }^{11}$ Ebben a percepciós sémában a környezeti értékek aligha kerülhetnek a legfontosabbak közé, miként ezt a kérdéskörrel kapcsolatos értékszociológiai vizsgálatok is igazolják (Luijkx 2017). ${ }^{12}$

A környezeti értékek melletti elköteleződésnek ebben a régióban is megvannak a miliöstrukturális jegyei, természetesen a régió fejlődéséből fakadó különbségekkel. Osztozik e régió a nyugatival abban a tekintetben, hogy a posztmateriális értékekhez sorolható környezeti értékek iránti elköteleződés különbözik az egyes életkori csoportokban. Annyiban társadalomtörténetileg kondicionált ez, hogy azok az értékek válnak alapvető tájékozódási ponttá, amelyek az adott nemzedék öneszmélésében, önmeghatározásában nagy jelentőséggel bírnak. Az eltérő társadalmi tapasztalat miatt az idősebb generációknál kevésbé, a fiatalabbaknál inkább jellemző a környezeti értékek mentén való tájékozódás. Emellett itt is jelen van az a sajátosság, hogy generációkon belül is mutatkoznak különbségek az értékek tekintetében attól függően, hogy milyen élménysémával reflektálnak a világra. A környezeti értékek preferálása itt is a képzettebb, az élménysémájában a kontemplációra és a társadalmi környezet iránt nagyobb affinitást mutató miliő tagjainál lesz erősebb. ${ }^{13}$ Magyarországon is ők jelentik a környezetvédelem mellett elkötelezettek legerőteljesebb, a nyilvánosságban leginkább látható, és így a társadalmi kommunikációra leginkább hatók csoportját. ${ }^{14}$

Jelentősen eltér azonban a nyugati régiótól, hogy a mi térségünkben a képzett fiatalok miliője miként viszonyul a környezeti kérdésekhez, ami következik az előbbiekben leírt társadalmi struktúra jegyeiből. Egy olyan szerkezetben, ahol a politikával megjelenített központi

11 Magyarország és általában a kelet-közép-európai régió sajátossága az, hogy az utóbbi évtizedekben nemhogy növekedett volna a posztmateriális értékek mentén tájékozódók részaránya, hanem csökkent (Halman és Voicu 2010: 43). A materiális értékek preferálása mutatkozik meg abban is, hogy az 1990-es években a fejlődő országokkal (Nigériával, Indiával) vetekedve a lista élén szerepelt az ország a tekintetben, hogy nálunk értettek egyet legtöbben azzal a kijelentéssel, hogy a munkanélküliség felszámolásához el kell fogadnunk a környezetszennyezést (Inglehart, Basanez és Moreno 1998). (Ugyanez a kutatás állapítja meg azt is, hogy a magyarok - az olaszokkal és a portugálokkal együtt - értenek egyet a leginkább abban, hogy a környezetvédelmet csak úgy támogatnák, ha az nekik semmi költséget nem jelentene.)

12 A környezetvédelem ügye melletti alacsony elköteleződést több adat is mutatja ebben a kutatásban. Egyrészt európai összehasonlításban nagyon alacsony azoknak a száma Magyarországon, akik környezetvédelemmel kapcsolatos önkéntes munkát végeznek. Másrészt hosszabb idősávban (1990 és 2008 között) is az látszódik, hogy csökkent azoknak a száma, akik pénzt adnának a környezetvédelemre. (A magyarok sajátos fatalizmusa jelenik meg abban, hogy a fenti adatok mellett a megkérdezettek kiemelkedően magas aránya, 88\%-a gondolja azt, hogy hamarosan környezeti katasztrófa fog bekövetkezni.)

13 Nálunk is érvényesül az a nyugaton is megfigyelt sajátosság, hogy a környezeti értékek melletti elköteleződés az életkorral, az iskolai végzettséggel és (kisebb mértékben) a jövedelemmel korrelál: minél fiatalabb, minél képzettebb és minél vagyonosabb valaki, annál inkább nyitott a környezeti értékekre (Inglehart, Basanez és Moreno 1998).

14 Más kérdés, hogy a környezetvédelemmel foglalkozó fiatalok elsősorban a nyugati protesztmozgalmak akcióinak („school strike for climate”, „fridays for future”, „zero waste moment”) átvételére fókuszálnak. Nem nagyon látni eredeti, helyi ötleteket, amelyek önálló kezdeményezéseken alapulnának. Mindenesetre már az is pozitívum, hogy csatlakoznak azokhoz a nemzetközi mozgalmakhoz, amelyek egy globális probléma kezelésére szerveződtek. 
hatalomnak jóval nagyobb súlya van a társadalmi valóság meghatározásában, ez a befolyás az egyes miliők percepciós sémájában is megmutatkozik. Ahol a politika hatóköre nagyobb eséllyel formálja az egyes részrendszerekhez tartozó kommunikációk tartalmát, ott a politika alapvetően képes hatást gyakorolni a személyek perspektívájára is. Mivel a modern társadalomban az egyének alapvetően a személyes karrier vonatkozásában tájékozódnak a társadalmi térben (Luhmann 1993c), a politika hatása leginkább az egyéneknek a karrieresélyekhez füződő viszonyában jelenik meg. Mindez az egyének mérlegelésében akkor jelenik meg, amikor a pálya- vagy munkahelyválasztás során megvizsgálják, hogy az adott státusz betöltése milyen, a politikai hatalom által megfogalmazott elvárásokkal jár együtt. A társadalom minden területén (a médiában, oktatásban, tudományban, jogszolgáltatásban, művészetben, sportban stb.) jelen lévő politika pedig mindezeken a területeken határozott elvárásokat fogalmaz meg az értékek tekintetében. Sőt ennél többről is szó van: a politikai hatalom saját értékei melletti nyilvános elköteleződés gyakran az elvárt lojalitáson túl a munkaköri „alkalmasságnak” is a feltétele.

A vázolt strukturális jegyek értelemszerüen nem csupán a részrendszerek autonómiáját gyakran felülíró, alacsony adaptációs képességü társadalmi berendezkedést eredményeznek, hanem a környezeti értékekhez füződő viszonyt is alapvetőn befolyásolják. A képzett fiatalok miliője esetében ez azt jelenti, hogy az élményorientációk közé bekerülnek olyanok is, amelyeket a hatalmi viszonyok kondicionáltak, és amelyek a saját sémákat részben felülírják, ami olyan társadalmi tájékozódást eredményez, amely nagyban korlátozza a környezeti értékek iránti elköteleződés esélyét. Meglátásom szerint ez egy olyan „percepciós skizofréniában” jelenik meg, ahol a miliő tagjai egyrészt arra kondicionálódtak, hogy élménysémájuknak megfelelően a környezeti értékek elsődleges támogatói legyenek, másrészt viszont a politika túlsúlyos hatalmával jellemezhető munkaerőpiacon arra kényszerülnek, hogy a kontraszelektált piaci versenyben karrieresélyeiket a közhatalom környezeti kérdéseket partikulárisnak nevező, vagy azt egyenesen negligáló kommunikációja mellett köteleződjenek el nyilvánosan. (Ez a zömében a politikai ciklusokon átívelő sajátosság jelen pillanatban abban mutatkozik meg, hogy a miliő élménysémáját felülírni látszik a miliő tagjainak a NER-hez füződő viszonya.)

A képzett, társadalmi vonatkozásban is tájékozódni tudó, elvileg már a környezeti kérdések iránt is affinitással rendelkező fiatal generációk tehát nem képviselik egységesen a környezeti értékeket, hanem megosztottak a kérdéskör kapcsán. (Ezt látjuk például abban, hogy míg az elvileg ugyanolyan élménysémával rendelkező miliő egyik tagja az utcán tüntet a környezeti értékek hangsúlyosabb társadalmi jelenléte érdekében, addig a miliő másik tagja a közmédiának nevezett kormánypropaganda alkalmazottjaként mindent elkövet a tüntetők karaktergyilkossága érdekében.) Ez a megosztottság értelemszerüen nem csupán a környezeti kérdések iránti elköteleződés társadalmi súlyát és hatékony képviseletét csökkenti. A fenti sajátosság most nem is elsősorban a társadalmi patológiák és pszichopatológiák természetrajza miatt érdekes (vö. Sik 2015), hanem ebben az összefüggésben inkább arra irányítanám a figyelmet, hogy ez a struktúrából következő sajátosság a miliő tagjainak a környezeti értékekhez füződő viszonyában megjelenő élményparadigmáját - felettébb szerencsétlen módon - a politikához kapcsolja.

Mint utaltam rá, a miliő élménysémája a saját szubjektivitását a társadalom előtt sikeresen megjelenítő személyre fókuszál. A társadalmi részrendszerek autonómiáját biztosító nyugati régióban a „befutottság” élménye sok területhez kapcsolódhat és nagyon kevéssé 
meghatározott a politikum szférája által. A fentiekben sorra vett strukturális jegyek nálunk azonban azt eredményezik, hogy a miliő tagjainak a környezeti értékekhez füződő viszonyát a sok tekintetben omnipotenciával jellemezhető politikához füződő viszony határozza meg. A környezeti értékek képviseletének alacsonyabb arányán túl ez azt is eredményezi, hogy a környezeti értékekhez füződő viszonyra rátelepszik a politika. A környezetvédelem ügye ekképpen nagyobb eséllyel tud pártpolitikai identitások, elköteleződések részeként megjelenni, ami magától értetődően növeli a környezetvédelem kérdésében megosztottak számát. Óhatatlanul az a következménye ennek, hogy nálunk a környezeti értékek inkább a politikai szekértáborok síkján jelennek meg. A kérdéshez füződő viszony tehát nem elsősorban morális problémaként jelenik meg; vagyis nem olyan alapvető értékek mentén, amelyek a közös értékekben osztozó társadalom integrációját biztosítanák.

A felülről megszervezett közhatalom túlsúlya, a társadalmi részrendszerek csekélyebb hatóköre, a domináns helyzetben lévő politika által kondicionált közélet és „életvilág”, a hosszú távú emlékezetnek híján lévő és ezért a döntések közép- és hosszú távú következményeit is kevésbé mérlegelő közhatalom, a posztmateriális értékek alacsony súlyú, sőt csökkenő jelenléte, a társadalom miliőstrukturális szerveződésére is rátelepedő politika csak a legfőbb tényezők azok közül, amelyek a kelet-közép-európai régió sajátosságait megmutatják. Ezek az összetevők hatnak a leginkább arra, hogy a környezeti értékek milyen társadalmi szereppel rendelkeznek. Ezzel magyarázható, hogy nálunk az ökológiai kommunikáció a nyugati régiónál kisebb mértékben tudja a környezeti értékeket közvetíteni, amiből adódóan kevésbé tudja irritálni az egyes részrendszerek racionalitását, és kisebb eséllyel tud új impulzusokat adni az átpolitizált, a környezeti kihívásokra csak csekély affinitást mutató közhatalomnak. Meglátásom szerint ezek a strukturális tényezők játsszák a legnagyobb szerepet abban, hogy Magyarországon a kétségtelenül megnövekedett láthatósága ellenére a környezetvédelem ügye még mindig csak partikuláris kérdésként jelenik meg a társadalmi kommunikációban.

\section{Hivatkozott irodalom}

Angelusz Róbert (2003): Amíg hírekként megjelennek... Az eseményektől a hírekig. Jel-Kép 24(3): 3-23.

Antal Attila (2014): Ökopolitika, ideológia, baloldal. Egy baloldali környezetpolitika alapjai. Budapest: L’Harmattan. Antal Z. László (2015): Klímaparadoxonok. Lehet-e harmónia természet és társadalom között? Budapest: L'Harmattan. Bajomi-Lázár Péter (2013): The Party Colonisation of the Media. The Case of Hungary. East European Politics and Societies 27(1): 67-87. DOI: https://doi.org/10.1177/0888325412465085

Bajomi-Lázár Péter és Horváth Dorka (2013): The Continued Relevance of Propaganda. Propaganda as Ritual in Contemporary Hungary. Global Media And Communication 9(3): 219-237. DOI: https://doi. org/10.1177/1742766513504174

Bartus Gábor (2017): Miért nem képesek a társadalmak megfékezni a természeti környezet pusztulását? Az érdemi és hatékony környezetpolitika körvonalai. In Hegymenet. Társadalmi és politikai kihívások Magyarországon. Jakab András és Urbán László (szerk.). Budapest: Osiris, 431-452.

Benda Gyula (1991): Van-e közép-európai társadalomfejlődési modell? Európai Fórum 1(2): 18-27.

Benda Gyula (1997): A társadalomtörténet-írás helyzete és perspektívái. Századvég 2(4): 33-42.

Berger, Peter L. és Thomas Luckmann (1998): A valóság társadalmi felépitése. Tudásszociológiai értekezés. Budapest: Jószöveg.

Berger Viktor (2008): Életstílus- és miliőkutatások a német szociológiában. A hagyományos struktúramodellek alternatívái? Replika (64-65): 115-130. Interneten: http://www.replika.hu/replika/64-06.

Bibó István (2016): A magyar társadalomfejlődés és az 1945. évi változás értelme. In Bibó István összegyüjtött írásai 2. Dénes Iván Zoltán (szerk.). Budapest: Kalligram, 265-279.

Boda Zsolt és Scheiring Gábor (2006): Zöld közpolitika-befolyásolás az EU-ban. Politikatudományi Szemle 15(4): 41-74. 
Bod Péter Ákos (2018): Bérek, profitok és járadékok harca - magyar szemmel. Századvég (88): 51-74.

Bod Péter Ákos (2019a): Megint utat tévesztünk? Gazdaságunk állapotáról, kockázatairól és kilátásairól. Budapest: Noran Libro.

Bod Péter Ákos (2019b): A mi „brezsnyevi pangásunk” - Hat állítás a korrupcióról, a közjóról és a magánjavakról. Heti Válasz (2019. július 16.).

Bognár Bulcsu (2015): A könyvnyomtatás és a nyilvánosság szerepe a modern társadalom kialakulásában. Replika (95): 13-30. Interneten: http://www.replika.hu/replika/95-02.

Botvar, Pal Ketil (2005): The Moral Thinking of Three Generations in Scandinavia. What Role Does the Religion Play? Social Compass 52(2): 185-195. DOI: https://doi.org/10.1177/0037768605052601

Brunczel Balázs (2010): Modernitás illúziók nélkül. Niklas Luhmann társadalom- és politikaelmélete. Budapest: L'Harmattan.

Éber Márk Áron (2007): Élménytársadalom. Gerhard Schulze koncepciójának tudás- és társadalomelméleti összefüggéseiröl. Budapest: ELTE TÁTK.

Éber Márk Áron (2008): Túl az élménytársadalmon? avagy az élménytársadalom másfél évtizede. Szociológiai Szemle 18(1): 78-105.

Éber Márk Áron (2009): A megfigyelő megfigyelése. Luhmann megfigyelőfogalmától a „magyar társadalom” kulturális tagolódásának vizsgálatáig. In Látás, tekintet, pillantás. A megfigyelés lehetőségei. Kovács és Orbán és Kasznár (szerk.). Budapest: Gondolat, 87-99.

Festinger, Leon (2000): A kognitív disszonancia elmélete. Budapest: Osiris.

Finke, Roger és Adamczyk, Amy (2008): Cross-national Moral Beliefs. The Influence of National Religious Context. Sociological Quarterly 49(4): 617-652. DOI: https://doi.org/10.1111/j.1533-8525.2008.00130.x

Fordulat (2019): Klímaváltozás és kapitalizmus. A Fordulat folyóirat tematikus (25.) száma.

Gajduschek György (2017): A haza szolgálatában? A közigazgatás reformjai(i). In Hegymenet. Társadalmi és politikai kihívások Magyarországon. Jakab András és Urbán László (szerk.). Budapest: Osiris, 229-250.

Gerschenkron, Alexander (1984): A gazdasági elmaradottság történeti távlatból. Tanulmányok. Budapest: Gondolat.

Habermas, Jürgen (1993): A társadalmi nyilvánosság szerkezetváltozása. Budapest: Századvég - Osiris.

Habermas, Jürgen (2011): A kommunikatív cselekvés elmélete. Budapest: Gondolat.

Hajnal István (1942a): Az osztálytársadalom. In Magyar Müvelödéstörténet V. Az új Magyarország. Domanovszky Sándor (főszerk.). Szekszárd: Babits Magyar-Amerikai Kiadó, 153-201.

Hajnal István (1942): A kis nemzetek történetírásának munkaközösségéröl 1-2. Századok 76(1-3., 4-6.) 1-42. és 133-165.

Hajnal István (1988): Az újkor története. (Egyetemes történet négy kötetben. Harmadik kötet. Újkor.) Budapest: Athenaeum Kiadó.

Hajnal István (1989): Kézművesség, írásbeliség és európai fejlődés. Századok 123(3-4): 407-426.

Hajnal István (1993): Technika, müvelödés. Tanulmányok. Glatz Ferenc (szerk.). Budapest: MTA Történettudományi Intézet.

Hajnal István (1998): Írásbeliség és fejlődés. Replika (30): 195-210.

Halman, Loek és Malina Voicu (2010): Mapping Value Orientations in Central and Eastern Europe. Leiden: Brill.

Herczeg Ferenc (2005): A gótikus ház. Emlékirat. Pomáz: Kráter.

Inglehart, Ronald (1977): The Silent Revolution. Changing Values and Political Styles among Western Publics. Princeton: Princeton University Press.

Inglehart, Ronald (1997): Modenization and Postmodernization. Princeton: Princeton University Press.

Inglehart, Ronald és Wayne E. Baker (2000): Modernization, Cultural Change, and the Persistence of Traditional Values. American Sociological Review 65(1): 19-51.

Inglehart, Ronald és Christian Welzel (2005): Modernization, Cultural Change, and Democracy. The Human Development Sequence. Cambridge: Cambridge University Press.

Jahraus, Oliver (2012): Supertheorie? In Luhmann Handbuch. Leben - Werk - Wirkung. Olivier Jahraus és Armin Nassehi (szerk.). Stuttgart: J. B. Metzler, 432-436.

Joas, Hans (2000): The Genesis of Values. Chicago: University of Chicago Press.

Joas, Hans (2019): „Fridays for Future” als Religion? Alle verehren Greta. (Anna Sauerbrey interjúja.) Der Tagesspiegel (2019. április 20.).

Karácsony András (1987a): Ökológiai problémák és a modern társadalom. Valóság 30(6): 102-104.

Karácsony András (1987b): A jog szociológiai megfigyelése. ELTE ÁJK Actái 29: 231-233.

Karácsony András (1990): Niklas Luhmann társadalomelmélete és az autopoiézisz. Szociológia 19(1-2): 1-29.

Karácsony András (2000): Rendszer, autopoiészisz, kommunikáció. In Német társadalomelméletek. Témák és trendek 1950-től napjainkig. Balogh István és Karácsony András. Budapest: Balassi, 269-329. 
Keller Tamás (2010): The Position of Hungary on Worldwide Map of Human Values. Review of Sociology of the Hungarian Socilogical Association 20(1): 27-51.

Kemény István (2010): Előadások a magyar társadalomfejlödés szociológiájáról. Szeged: Belvedere Meridionale.

Kemény Zsigmond (1843-1844): Korteskedés és ellenszerei. Kolozsvár: Királyi Lyceum.

Lányi András (1994): Az ökopolitika esélyei. Liget 7(5): 5-7.

Lányi András (1999): Együttéléstan. A humánökológia a politikai filozófiában. Budapest: Liget Mühely Alapítvány.

Lányi András (2000): Utószó: miért lehetetlen, ha muszáj? In Természet és szabadság. Humánökológiai olvasókönyv. Lányi András (szerk.). Budapest: ELTE - Osiris, 279-281.

Lányi András (2007): A fenntartható társadalom. Budapest: L'Harmattan.

Lányi András (2010a): Az ember fáj a földnek. Utak az ökofilozófiához. Budapest: L’Harmattan.

Lányi András (2010b): Miért fenntarthatatlan, ami fenntartható? A környezetbarát gazdálkodás és a közösségi vállalkozás esélyei egy aprófalvas régióban. In Miért fenntarthatatlan, ami fenntartható? Lányi András és Farkas Gabriella (szerk.). Budapest: L’Harmattan, 12-61.

Lányi András (2012): Az ökológia mint politikai filozófia. Politikatudományi Szemle 21(1): 105-130.

Lányi András (2015): Oidipusz, avagy a természetes ember. Budapest: Liget Mühely Alapítvány.

Lányi András és Farkas Gabriella (szerk.) (2010): Miért fenntarthatatlan, ami fenntartható? Budapest: L'Harmattan, Lányi András és Jávor Benedek (szerk.) (2005): Környezet és etika. Szöveggyüjtemény. Budapest: L'Harmattan.

Luijkx, Ruud et al. (2017): European Values in Numbers. Trends and Traditions at the Turn of the Century. Leiden - Boston: Brill.

Luhmann, Niklas (1969): Legitimation duch Verfahren. Berlin: Luchterhand.

Luhmann, Niklas (1977a): Differentiation of Society. Canadian Journal of Sociology 2(1): 29-53.

Luhmann, Niklas (1977b): Funktion der Religion. Frankfurt am Main: Suhrkamp.

Luhmann, Niklas (1981): Die Unwahrscheinlichkeit der Kommunikation. In uő Soziologische Aufklärung 3. Soziales System, Gesellschaft, Organisation. Opladen: Westdeutscher, 25-34.

Luhmann, Niklas (1989): Alternatívok alternatívák nélkül. In Politikai ökológia. Szemelvények a nyugati alternatív mozgalmak elméletéröl és politikájáról. Szabó Máté (szerk.). Budapest: ELTE, 187-189.

Luhmann, Niklas (1990): Die Wissenschaft der Gesellschaft. Frankfurt am Main: Suhrkamp.

Luhmann, Niklas (1991): Systemtheorie, Evolutionstheorie und Kommunikationstheorie. In uő Soziologische Aufklärung 2. Aufsätze zur Theorie der Gesellschaft. Opladen: Westdeutscher, 93-103.

Luhmann, Niklas (1991b): Die Weltgesellschaft. In uő Soziologische Aufklärung 2. Aufsätze zur Theorie der Gesellschaft. Opladen: Westdeutscher, 51-71.

Luhmann, Niklas (1993a): Gesellschaftliche Struktur und semantische Tradition. In uő Gesellschaftsstruktur und Semantik. Studien zur Wissenssoziologie der modernen Gesellschaft. Band 1. Frankfurt am Main: Suhrkamp. 9-71.

Luhmann, Niklas (1993b): Ethik als Reflexionstheorie der Moral. In uö Gesellschaftsstruktur und Semantik. Studien zur Wissenssoziologie der modernen Gesellschaft. Band 3. Frankfurt am Main: Suhrkamp, 358-447.

Luhmann, Niklas (1993c): Individuum, Individualität und Individualismus. In uö Gesellschaftsstruktur und Semantik. Studien zur Wissenssoziologie der modernen Gesellschaft. Band 3. Frankfurt am Main: Suhrkamp, 149-258.

Luhmann, Niklas (1995a): Die operative Geschlossenheit psychischer und sozialer Systeme. In uő Soziologische Aufklärung. Band 6. Der Mensch. Opladen: Westdeutscher, 26-37.

Luhmann, Niklas (1995b): Das Recht der Gesellschaft. Frankfurt am Main: Suhrkamp.

Luhman, Niklas (1996a): Umweltrisiko und Politik. In uő Protest. Systemtheorie und soziale Bewegungen. Frankfurt am Main: Suhrkamp. 160-174.

Luhmann, Niklas (1996b): Kann die moderne Geselschaft sich auf ökologische Gefährdungen einstellen? In Protest. Systemtheorie und soziale Bewegungen. Kai-Uwe Hellmann (szerk.). Frankfurt am Main: Suhrkamp, 46-63.

Luhmann, Niklas (1996c): Protestbewegungen. In Protest. Systemtheorie und soziale Bewegungen. Kai-Uwe Hellmann (szerk.). Frankfurt am Main: Suhrkamp, 201-215..

Luhmann, Niklas (1996d): Systemtheorie und Protesbewegungen. In Protest. Systemtheorie und soziale Bewegungen. Kai-Uwe Hellmann (szerk.). Frankfurt am Main: Suhrkamp, 175-200.

Luhmann, Niklas (1996e): Das trojanische Pferd. In Protest. Systemtheorie und soziale Bewegungen. Kai-Uwe Hellmann (szerk.). Frankfurt am Main: Suhrkamp, 64-74.

Luhmann, Niklas (1998a): Die Gesellschaft der Gesellschaft I-II. Frankfurt am Main: Suhrkamp.

Luhmann, Niklas (1998b): Die Wirtschaft der Gesellschaft. Frankfurt am Main: Suhrkamp.

Luhmann, Niklas (1999a): Látom azt, amit te nem látsz. Budapest: Osiris.

Luhmann, Niklas (1999b): Die Behandlung von Irritationen: Abweichung oder Neuheit? In uő Gesellschaftsstruktur und Semantik. Studien zur Wissenssoziologie der modernen Gesellschaft. Band 4. Frankfurt am Main: Suhrkamp, 55-100. 
Luhmann, Niklas (2000): Die Religion der Gesellschaft. Frankfurt am Main: Suhrkamp.

Luhmann, Niklas (2002a): Die Politik der Gesellschaft. Frankfurt am Main: Suhrkamp.

Luhmann, Niklas (2002b): Das Erziehunssystem der Gesellschaft. Frankfurt am Main: Suhrkamp.

Luhmann, Niklas (2005): Einführung in die Theorie der Gesellschaft. Dirk Baecker (szerk.). Heidelberg: Carl-Auer.

Luhmann, Niklas (2008a): Die Moral der Gesellschaft. Detlef Horster (szerk.). Frankfurt am Main: Suhrkamp.

Luhmann, Niklas (2008b): Soziologie der Moral. In uő Die Moral der Gesellschaft. Frankfurt am Main: Suhrkamp, 56-162.

Luhmann, Niklas (2008c): Politik, Demokratie, Moral. In uő Die Moral der Gesellschaft. Frankfurt am Main: Suhrkamp, 175-195.

Luhmann, Niklas (2008d): Paradigm lost. Über die ethische Reflexion der Moral. In uő Die Moral der Gesellschaft. Frankfurt am Main: Suhrkamp, 253-269.

Luhmann, Niklas (2008e): A tömegmédia valósága. Budapest: Gondolat - AKTI.

Luhmann, Niklas (2009a): Az ismeret: konstrukció. Replika (66): 17-31. Interneten: http://replika.hu/replika/66-02.

Luhmann, Niklas (2009b): Szociális rendszerek. Budapest: Gondolat - AKTI.

Luhmann, Niklas (2009c): Interszubjektivitás vagy kommunikáció. A szociológiai elméletalkotás eltérő kiindulópontjai. Replika (66): 33-48. Interneten: http://replika.hu/replika/66-03.

Luhmann, Niklas (2010a): Ökológiai kommunikáció. Képes-e felkészülni a modern társadalom az ökológiai veszélyekre? Budapest: Gondolat - AKTI.

Luhmann, Niklas (2010b): A tudatlanság ökológiája. In uő A modernség megfigyelései. Budapest: AKTI - Gondolat, 93-136.

Mannheim Károly (2000): A nemzedékek problémája. In uő Tudásszociológiai tanulmányok. Budapest: Osiris, 201-253.

Mellár Tamás (2017): Nincsenek bombabiztos receptek. Gazdaságpolitikai alternatívák a modernizációra. In Hegymenet. Társadalmi és politikai kihívások Magyarországon. Jakab András és Urbán László (szerk.). Budapest: Osiris, 251-264.

Ohnsorge Szabó László, Kajner Péter és Ungvári Gábor (2005): Fenntartható EU felé (?). Kritikai elemzés az EU és Magyarország környezetpolitikájáról. Budapest: L'Harmattan.

Ortega y Gasset, José (2003): Korunk feladata. Budapest: Napvilág.

Parsons, Talcott (1949): The Structure of Social Action. Glencoe, Ill.: Free Press.

Parsons, Talcott (1968): On the Concept of Value-Commitments. Social Inquiry 38(2): 135-160.

Peters, Bernhard (2007): A nyilvánosság jelentése. In Média, nyilvánosság, közvélemény. Angelusz Róbert, Tardos Róbert és Terestyéni Tamás (szerk.). Budapest: Gondolat, 614-632.

Pokol Béla (1995): Médiahatalom. Válogatott írások. Budapest: Windsor.

Pokol Béla (2005): A morál és az erkölcs szerepe a modern társadalmakban. Jogelméleti Szemle 6(3): 1-19.

Pokol Béla (2010): Morálelméleti vizsgálódások. A közmorál elméleti eltüntetésének kritikája. Budapest: Kairosz.

Rasch, William (2012): Eine „deutsche” grand theory? In Luhmann Handbuch. Leben - Werk - Wirkung. Olivier Jahraus és Armin Nassehi (szerk.). Stuttgart: J. B. Metzler, 437-440.

Scheepers, Peer, Mérove Gijsberts és Evelyn Hello (2002): Religiosity and Prejudice against Ethnic Minorities in Europe. Cross-national Tests on a Controversial Relationship. Review of Religious Research 48(3): 242-265. DOI: https://doi.org/10.2307/3512331

Scheiring Gábor (2008): A környezetvédelem repolitizálódása. Ökopolitikai értelmezési keretek dinamikája a Zengő-Mozgalomban. Szociológiai Szemle 18(2): 111-130.

Schulze, Gerhard (1992): Die Erlebnisgesellschaft. Kultursoziologie der Gegenwart. Frankfurt am Main: Campus.

Sik Domonkos (2015): Társadalmi patológia és pszichopatológia. A pszichológiai diagnózisok és terápiák haszna a kritikai elmélet számára. socio.hu 5(3): 197-222. DOI: https://doi.org/10.18030/socio.hu.2015.3.197

Stichweh, Rudolf (2000): Die Weltgesellschaft. Soziologische Analysen. Suhrkamp: Frankfurt am Main.

Szücs Jenő (1983): Vázlat Európa három történeti régiójáról. Budapest: Magvető.

Storm, Indrid (2009): Halfway to Heaven. Four Types of Fuzzy Fidelity in Europe. Journal for the Scientific Study of Religion 48(4): 702-718. DOI: https://doi.org/10.1111/j.1468-5906.2009.01474.x

Storm, Ingrid (2016): Morality in Context. A Multilevel Analysis of the Relationship between Religion and Values in Europe. Politics and Religion 9(1): 111-138. DOI: https://doi.org/10.1017/S1755048315000899

Takács-Sánta András (2009): Kiútlehetőségek a környezeti válságból. Vázlat a közlegelők tragédiája elkerülésének lehetőségeiröl. Kovász 13(1-4): 3-12.

Takács-Sánta András (2017): A közlegelők komédiája. A közösségek újrafelfedezése mint kiút az ökológiai válságból. Budapest: L'Harmattan.

Taylor, Charles (2007): A Secular Age. Cambridge: Harvard University Press. 
Tóth István György (2010): A társadalmi kohézió elemei: bizalom, normakövetés, igazságosság és felelősségérzet lennének... In Társadalmi riport 2010. Kolosi Tamás és Tóth István György (szerk.). Budapest: TÁRKI, 254-287. Vida Gábor (2016): Szétszabdalt tudomány, komplex problémák. In Ökológiai lábnyom és fenntarthatatlanság. Horváth Balázs (szerk.). Budapest: L’Harmattan, 245-251.

if. Zlinszky János (2001): A környezet fogalma az alkotmányban. In A szag nyomában. Környezeti konfliktusok és a helyi társadalom. Lányi András (szerk.). Budapest: Osiris, 318-325.

\section{Bognár Bulcsu}

Szociológus, egyetemi docens, PPKE Kommunikáció- és Médiatudományi Intézet (Budapest) 
